\title{
Speciated measurements of semivolatile and intermediate volatility organic compounds (S/IVOCs) in a pine forest during BEACHON-RoMBAS 2011
}

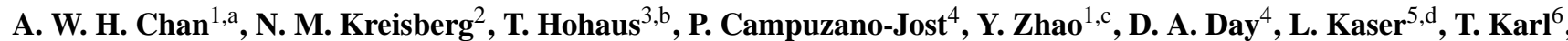 \\ A. Hansel $^{5}$, A. P. Teng ${ }^{2, \mathrm{e}}$, C. R. Ruehl ${ }^{1, \mathrm{f}}$, D. T. Sueper ${ }^{3,4}$, J. T. Jayne ${ }^{3}$, D. R. Worsnop ${ }^{3}$, J. L. Jimenez ${ }^{4}$, S. V. Hering ${ }^{2}$, \\ and A. H. Goldstein ${ }^{1}$ \\ ${ }^{1}$ Department of Environmental Science, Policy, and Management, University of California, Berkeley, California, USA \\ ${ }^{2}$ Aerosol Dynamics Inc., Berkeley, California, USA \\ ${ }^{3}$ Aerodyne Research Inc., Billerica, Massachusetts, USA \\ ${ }^{4}$ Department of Chemistry and Biochemistry, University of Colorado, Boulder, Colorado, USA \\ ${ }^{5}$ Institut für Ionenphysik \& Angewandte Physik, University of Innsbruck, Innsbruck, Austria \\ ${ }^{6}$ National Center for Atmospheric Research, Boulder, Colorado, USA \\ ${ }^{a}$ now at: Department of Chemical Engineering and Applied Chemistry, University of Toronto, Toronto, Ontario, Canada \\ ${ }^{b}$ now at: Forschungszentrum Jülich, Jülich, Germany \\ ${ }^{c}$ now at: Department of Mechanical Engineering, Carnegie Mellon University, Pittsburgh, Pennsylvania, USA \\ ${ }^{d}$ now at: National Center for Atmospheric Research, Boulder, Colorado, USA \\ ${ }^{e}$ now at: Division of Engineering and Applied Science, California Institute of Technology, Pasadena, California, USA \\ f now at: California Air Resources Board, Sacramento, California, USA
}

Correspondence to: A. W. H. Chan (arthurwh.chan@utoronto.ca)

Received: 14 July 2015 - Published in Atmos. Chem. Phys. Discuss.: 20 August 2015

Revised: 22 December 2015 - Accepted: 13 January 2016 - Published: 2 February 2016

\begin{abstract}
Understanding organic composition of gases and particles is essential to identifying sources and atmospheric processing leading to organic aerosols (OA), but atmospheric chemical complexity and the analytical techniques available often limit such analysis. Here we present speciated measurements of semivolatile and intermediate volatility organic compounds (S/IVOCs) using a novel dual-use instrument (SV-TAG-AMS) deployed at Manitou Forest, CO, during the Bio-hydro-atmosphere interactions of Energy, Aerosols, Carbon, $\mathrm{H}_{2} \mathrm{O}$, Organics \& Nitrogen - Rocky Mountain Biogenic Aerosol Study (BEACHON-RoMBAS) 2011 campaign. This instrument provides on-line speciation of ambient organic compounds with $2 \mathrm{~h}$ time resolution. The species in this volatility range are complex in composition, but their chemical identities reveal potential sources. Observed compounds of biogenic origin include sesquiterpenes with molecular formula $\mathrm{C}_{15} \mathrm{H}_{24}$ (e.g., $\beta$-caryophyllene and longifolene), which were most abundant at night. A variety of other biogenic compounds were observed, including sesquiterpenoids with
\end{abstract}

molecular formula $\mathrm{C}_{15} \mathrm{H}_{22}$, abietatriene and other terpenoid compounds. Many of these compounds have been identified in essential oils and branch enclosure studies but were observed in ambient air for the first time in our study. Semivolatile polycyclic aromatic hydrocarbons (PAHs) and alkanes were observed with highest concentrations during the day and the dependence on temperature suggests the role of an evaporative source. Using statistical analysis by positive matrix factorization (PMF), we classify observed S/IVOCs by their likely sources and processes, and characterize them based on chemical composition. The total mass concentration of elutable S/IVOCs was estimated to be on the order of $0.7 \mu \mathrm{g} \mathrm{m}^{-3}$ and their volatility distributions are estimated for modeling aerosol formation chemistry. 


\section{Introduction}

Large amounts of biogenic volatile organic compounds (BVOCs) are emitted by vegetation into the atmosphere. While some BVOCs are relatively unreactive (such as methanol and acetone), terpenoid compounds, such as isoprene, monoterpenes $\left(\mathrm{C}_{10} \mathrm{H}_{16}\right)$ and sesquiterpenes $\left(\mathrm{C}_{15} \mathrm{H}_{24}\right)$, are highly reactive and have large effects on local and global atmospheric chemistry (Hallquist et al., 2009; Williams, 2004). BVOCs undergo oxidation reactions to produce ozone in polluted regions (Chameides et al., 1988). These reactions also lead to low-volatility species, which are thought to be the dominant source of global secondary organic aerosol (SOA) (Griffin et al., 1999b; Henze and Seinfeld, 2006). Therefore, to understand current and future air quality and global climate, it is important to measure the chemical composition and atmospheric concentrations of these reactive BVOCs.

There has been ample evidence that currently not all reactive BVOCs are measured in the atmosphere of forests. For example, the reactivity against oxidants, such as the hydroxyl $(\mathrm{OH})$ radical and ozone, is often used as a proxy for total amount of reactive hydrocarbons. Many field studies have shown that measured BVOCs contribute only a fraction of the total $\mathrm{OH}$ reactivity, indicating incomplete understanding of reactive BVOCs (Di Carlo et al., 2004; Kim et al., 2011; Sinha et al., 2010; Nölscher et al., 2012). The discrepancy between total and expected $\mathrm{OH}$ reactivity depends strongly on temperature or plant stress, evidencing that biogenic emissions are likely responsible for the "missing" $\mathrm{OH}$ reactivity (Di Carlo et al., 2004; Nölscher et al., 2012). Similarly, ozone deposition in a pine forest appears to be dominated by reactive losses with BVOCs, but cannot be accounted for by currently measured species (Goldstein et al., 2004; Kurpius and Goldstein, 2003). Globally, the annual SOA production has been constrained to be around $150 \mathrm{Tg} \mathrm{C} \mathrm{yr}^{-1}$ in various studies using mass balance (Goldstein and Galbally, 2007), satellite observations (Heald et al., 2010), and aerosol mass spectrometer measurements (Heald et al., 2011; Spracklen et al., 2011). However, global models using existing VOC emission inventories predict annual SOA production to be around $40 \mathrm{Tg} \mathrm{C} \mathrm{yr}^{-1}$ (Hallquist et al., 2009). It is therefore likely that a potentially large pool of SOA-producing VOCs is missing from current models (Goldstein and Galbally, 2007). One modeling study indicates that an additional source of biogenically derived (anthropogenically controlled) SOA around $100 \mathrm{Tg} \mathrm{yr}^{-1}$ is needed to match observations by aerosol mass spectrometers (Spracklen et al., 2011), highlighting the need to properly account for biogenic SOAproducing sources. Recent evidence suggest that a group of extremely low-volatility organic compounds (ELVOCs) may be a significant contributor to $\mathrm{SOA}$ in forest atmospheres (Ehn et al., 2014; Jokinen et al., 2015).

Most published BVOC research efforts have focused on studying the emissions and oxidation chemistry of isoprene, 2-methyl-3-butene-2-ol (MBO) and monoterpenes, owing to their abundance. Other less volatile and often more reactive BVOCs, such as sesquiterpenes, are challenging to measure and are present in lower concentrations (Duhl et al., 2008; Pollmann et al., 2005). However, sesquiterpenes are highly reactive and can be a significant contributor to reactive loss of ozone in the forest canopy (Bouvier-Brown et al., 2009a, b; Jardine et al., 2011; Bourtsoukidis et al., 2012). Also, sesquiterpenes belong to a group of compounds known as intermediate volatility organic compounds (IVOCs), which have saturation concentrations, $c^{*}$, between $10^{3}$ and $10^{6} \mathrm{\mu g} \mathrm{m}^{-3}$ (Donahue et al., 2009). Together with semivolatile organic compounds (SVOCs, $c^{*}$ between 1 and $100 \mu \mathrm{g} \mathrm{m}^{-3}$ ), S/IVOCs have lower volatilities than traditional BVOCs, and are therefore more efficient SOA precursors. For example, sesquiterpenes have significantly higher SOA mass yields than monoterpenes (Chen et al., 2012; Griffin et al., 1999a; Lee et al., 2006a, b; $\mathrm{Ng}$ et al., 2007). These properties of sesquiterpenes (low concentrations, high reactivity, line losses) present significant analytical challenges, but measurements of these reactive, less volatile compounds are essential for understanding their sources and chemistry. Previous speciated measurements of SVOCs and organic aerosols in forests have involved collecting filter samples for offline analysis (Kallio et al., 2006; Rissanen et al., 2006). The collection times are typically long $(24 \mathrm{~h})$ and subject to compound degradation on filters (e.g., by reaction with ozone) (Rissanen et al., 2006). Also, atmospheric processes, such as transport and oxidation, occur on shorter timescales. In situ measurements of organic species are needed to minimize artifacts associated with sample collection, transport and storage, and to capture and help identify emissions sources and atmospheric processes that vary on the timescale of hours (Bouvier-Brown et al., 2009b; Worton et al., 2011).

In this work, in situ measurements of S/IVOCs were made in a pine forest during the BEACHON-RoMBAS field study. One of the objectives of the BEACHON-RoMBAS field study (and of this study) is to understand the biogenic and anthropogenic volatile organic compound emissions and their influences on regional atmospheric chemistry through chemical speciation (Ortega et al., 2014). Here we present hourly and bihourly speciated measurements of S/IVOCs and their tentative identifications to achieve this objective. Using statistical analysis by positive matrix factorization (PMF), we classify observed S/IVOCs by their likely sources and processes, and characterize them based on chemical composition. Their volatility distributions are estimated for modeling of aerosol formation chemistry.

\section{Experimental methods}

\subsection{Field location}

The measurements presented in this work were conducted as part of the Bio-hydro-atmosphere interactions of En- 


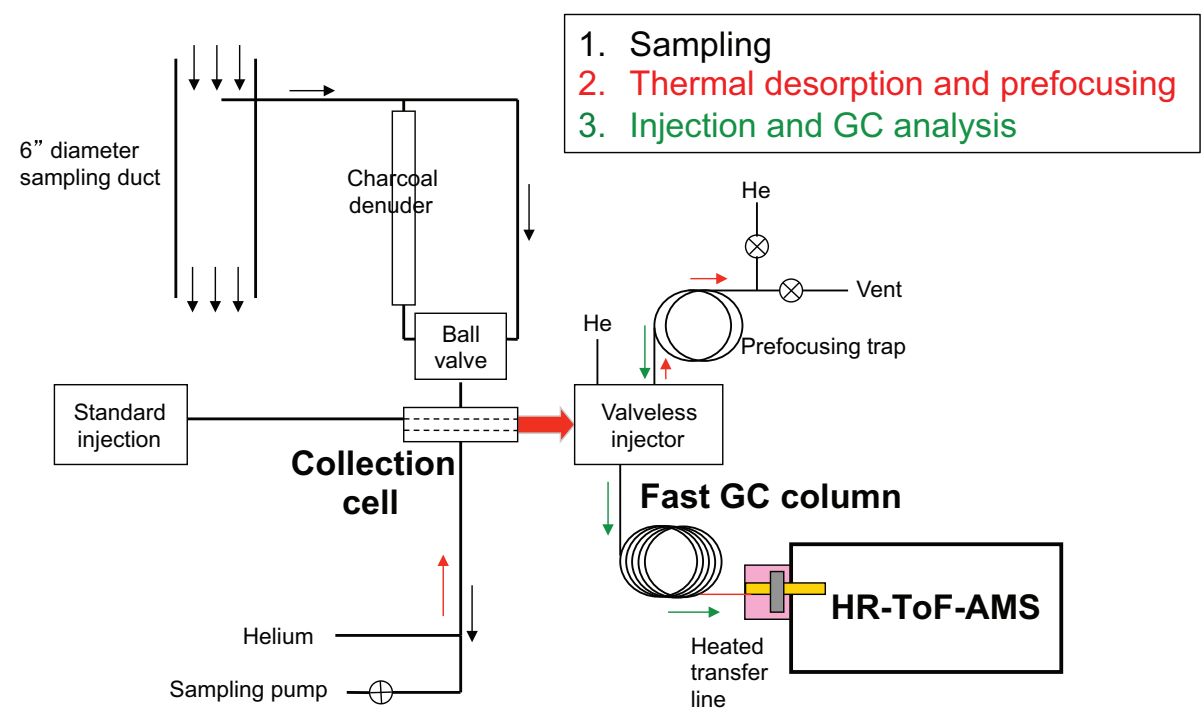

Figure 1. A schematic of the SV-TAG sample introduction system into the HR-ToF-AMS. The arrows in black, red, and green denote the flow paths during sample collection, thermal desorption and prefocusing, and injection into GC/MS analysis, respectively.

ergy, Aerosols, Carbon, $\mathrm{H}_{2} \mathrm{O}$, Organics \& Nitrogen (BEACHON) project, which seeks to understand the chemistry of gas and aerosol species in a mountainous semi-arid forest (Ortega et al., 2014). The field site, known as the Manitou Experimental Forest Observatory (MEFO, $39^{\circ} 6^{\prime} 2.16^{\prime \prime} \mathrm{N}$, $105^{\circ} 5^{\prime} 39.12^{\prime \prime} \mathrm{W}$ ), is located in the Front Range of the Colorado Rocky Mountains (Ortega et al., 2014). The wind patterns in this area are influenced by topographically induced flow. Nighttime flow below the canopy is often westerly or southwesterly, resulting in cleaner air arriving at the site from the forest. The vegetation in the area is mainly comprised of ponderosa pine and other conifers, with $\mathrm{MBO}$ and monoterpenes being the most abundant VOCs observed (Ortega et al., 2014). The average canopy height is $16 \mathrm{~m}$. Local chemistry is affected by urban emissions, as upslope flows from the northeast and the southeast are consistently observed, transporting air from Denver and Colorado Springs. Measurements presented in this work were conducted during the summer of 2011 between 19 and 30 August as part of BEACHONRoMBAS (Rocky Mountain Biogenic Aerosol Study). More details about the MEFO field site and the BEACHON project are described in a recent overview paper (Ortega et al., 2014).

\subsection{SV-TAG-AMS: speciated semivolatile organic measurements by GC/MS (SV-TAG)}

The purpose of the combined Thermal desorption Aerosol Gas chromatography - Aerosol Mass Spectrometer (TAGAMS) instrument is to provide simultaneous speciated and bulk measurements of aerosol particles (Williams et al., 2014). Here we deploy a custom version of TAG-AMS for sampling and analyzing S/IVOCs (Zhao et al., 2013b), known as the Semi-Volatile Thermal desorption Aerosol
GC/MS (SV-TAG-AMS). This work will focus on the speciated measurements of gas- and particle-phase organics. In this manuscript, we will refer to the combined instrument as SV-TAG-AMS, and the semivolatile GC/MS providing speciated organic measurements as SV-TAG. Specifically, we incorporate a few novel components into the system to improve performance and enable more quantitative analysis. These new components include (1) filter collection and thermal desorption cell (F-CTD) for gas- and particle-phase collection, (2) a GC system with on-column heating and (3) a custombuilt transfer line into the AMS. Components 2 and 3 will be incorporated into subsequent TAG-AMS configurations. The configuration of this instrument is illustrated in Fig. 1.

Samples were collected through a $15.2 \mathrm{~cm}$ diameter inlet sampling air $4 \mathrm{~m}$ above ground, while still under the canopy. The flow through the inlet was maintained by a fan pulling through a restriction at $150-200 \mathrm{~L} \mathrm{~min}^{-1}$ as measured by the pressure drop across an iris valve. During sampling, a subsampling flow of $10 \mathrm{~L} \mathrm{~min}^{-1}$ was drawn from the middle of the large inlet and through the collection cell. The filter collection and thermal desorption cell (F-CTD) is made of SS fiber filter and therefore has a high surface area $\left(\approx 1700 \mathrm{~cm}^{2}\right)$ for efficient collection and thermal transfer of S/IVOCs (Zhao et al., 2013b). Organic gases adsorb efficiently onto the filter surface, and particles are collected by filtration. The sample collection time was $30 \mathrm{~min}$ for the first 3 days, and 90 min subsequently. After sample collection was complete, organic compounds were thermally desorbed in helium at $320^{\circ} \mathrm{C}$ and transferred via a valveless interface to a focusing trap before injection into a GC column for analysis. Details of the valveless interface and SV-TAG instrument are described by Zhao et al. (2013b). The total time for filter desorption and GC analysis is $30 \mathrm{~min}$. As a result, 


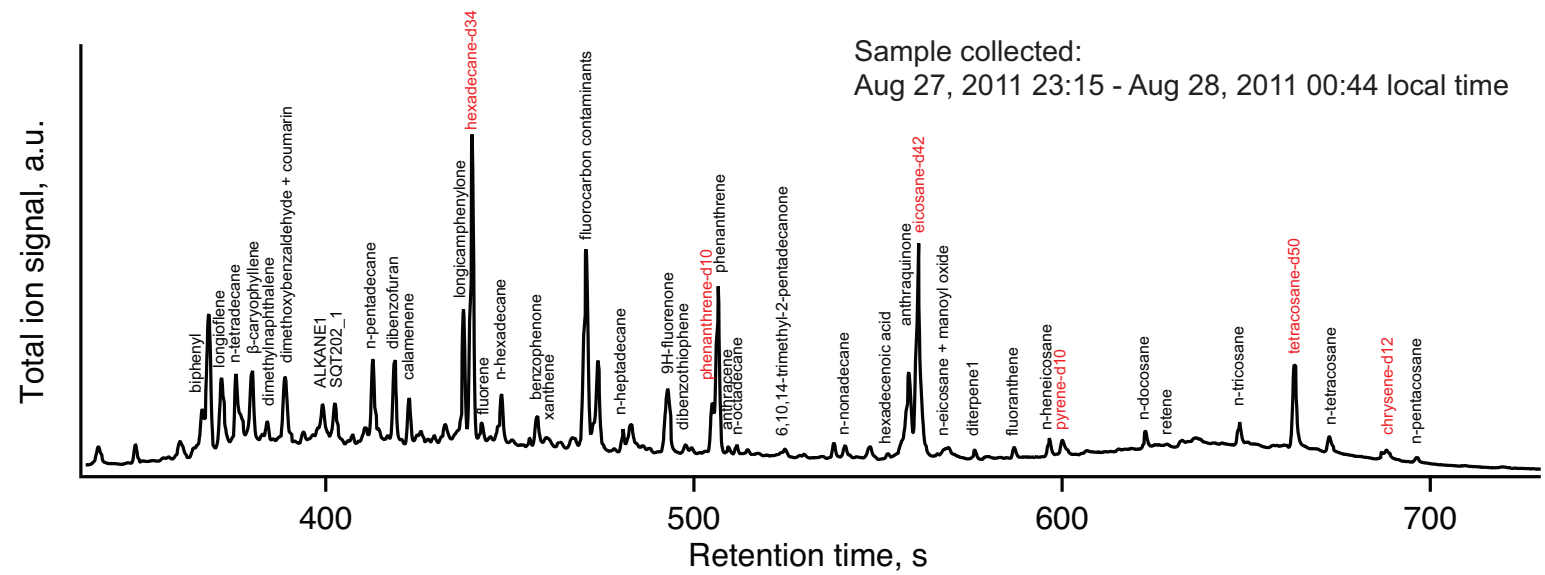

Figure 2. Total ion chromatogram of a typical sample. Deuterated internal standards (labeled in red) were injected prior to thermal desorption. The labeled compounds represent a subset of the compounds identified. More compounds were identified using the selected ion traces. A partial list of compounds tentatively identified is shown in Table 1, and the full list is shown in Table S1 in the Supplement.

the total sample turnaround time (sample collection + filter desorption + GC analysis) is 60 min (hourly time resolution) for the first 3 days, and 120 min (bihourly time resolution) subsequently.

Gas chromatographic separation was performed using a VICI Fast GC system (VICI, Houston, TX), which consists of a nickel clad GC column. The carrier gas is helium, and the column is a DB5-type column with a length of $15 \mathrm{~m}$ and an internal diameter of $0.18 \mathrm{~mm}$ and a film thickness of $0.25 \mu \mathrm{m}$. The column is resistively heated by applying a small current through its entire length, thereby eliminating the need of a column oven and reducing the instrument's power and space requirements. The column then interfaces with the AMS and delivers the effluent of the GC to the AMS electron impact ionizer via a custom-built transfer line heated to $320^{\circ} \mathrm{C}$. Details of the transfer line connection to the AMS are described by Williams et al. (2014).

\subsection{SV-TAG-AMS: bulk particle composition by HR-ToF-AMS (AMS TAG)}

This dual instrument is capable of bulk particle analysis by HR-ToF-AMS and S/IVOC collection on SV-TAG simultaneously. During S/IVOC collection on the SV-TAG cell, particles are introduced through the aerodynamic lens in the vaporizer/ionizer region in the AMS, and bulk particle composition is analyzed by electron impact high-resolution time-offlight mass spectrometry (DeCarlo et al., 2006). We will refer to this analysis as $\mathrm{AMS}_{\mathrm{TAG}}$, which includes measurements of sulfate and organic mass concentrations by HR-ToF-AMS on the combined SV-TAG-AMS system.

Upon completion of TAG sample collection, the sampling valve on the AMS inlet is closed and the chopper is moved to block the particle beam. AMS ${ }_{\mathrm{TAG}}$ analysis is therefore briefly paused, and the TAG sample is introduced through the GC and the transfer line to the same ionizer and mass spectrome- ter. While the bulk particle composition analysis by $\mathrm{AMS}_{\mathrm{TAG}}$ is not the focus of this work, we demonstrate in the Supplement (Fig. S5 and S6 in the Supplement) that the organic and sulfate mass concentrations measured by $\mathrm{AMS}_{\mathrm{TAG}}$ are within 10 and $5 \%$ of those measured by a collocated stand-alone HR-ToF-AMS (referred to as $\mathrm{AMS}_{\mathrm{STD}}$ ), respectively, indicating that the TAG inlet does not affect AMS operation, and the SV-TAG-AMS is capable of simultaneous bulk aerosol and speciated gas/aerosol measurements.

\subsection{Calibration and analysis of chromatographic data}

Compounds are first screened from peaks resolved in the total ion chromatogram, such as those shown in Fig. 2. In addition to these peaks, many more compounds are speciated from resolved peaks in the extracted ion chromatograms (chromatograms of select ion traces). Authentic standards (containing 34 compounds) injected during periodic calibrations are used to identify some compounds. For identifying other compounds, the background-subtracted mass spectra are matched to those in several mass spectral libraries, including the 2008 NIST/EPA/NIH mass spectral library, Adams essential oil library (Adams, 2007) and a proprietary library from MANE, a flavor and fragrance company. Match factors (Stein, 1994) of greater than 800 (out of 1000) are considered a good match for tentative identification. In some cases (such as alkanes and sesquiterpenes), isomers are found to yield match factors of 700-800. In those cases, while positive identification is not possible, information about the molecule type (such as alkane or sesquiterpene with molecular weight $204 \mathrm{amu}$ ) is still provided and compound naming reflects such information. Where available, literature retention indices are used to confirm or reject compound identification. The GC retention index of an organic compound $i$ is defined as 
$\mathrm{RI}_{i}=100 \times\left[n+(N-n)\left(\frac{t_{i}-t_{n}}{t_{N}-t_{n}}\right)\right]$,

where $n$ is the number of carbon atoms in the linear alkane eluting immediately before compound $i$, and $N$ is that in the alkane eluting immediately after compound $i$, and $t$ is the retention time. For example, $n$-tetradecane would have a retention index of 1400. Observed compounds are distinguished from cell desorption artifacts using periodic zero air blanks (passing ambient air through a charcoal filter into collection cell for $90 \mathrm{~min}$ ) and cell blanks (desorbing a cell with no sample collection). Zero air blanks were conducted once every 2 days, and cell blanks were conducted once every day at different hours of the day. Trace amounts of fluorocarbons are found to be present even during blanks, likely arising from fluoroelastomer seals in solenoid valves. A full list of compounds identified in the ambient atmosphere is shown in Table S1 in the Supplement (partial list in Table 1). All mass concentrations are reported in nanograms per cubic meter of air sampled at standard conditions ( $298 \mathrm{~K}, 1 \mathrm{~atm})$, abbreviated as $\mathrm{ng} \mathrm{sm}^{-3}$. Sesquiterpenes are also reported in pptv for comparison with PTR-TOF-MS data, by multiplying the mass concentration in $\mathrm{ng} \mathrm{sm}^{-3}$ by 204/24.45.

An automated standard injection system is used to deliver internal standards into the collection cell onto every sample immediately prior to thermal desorption (Isaacman et al., 2011a). The internal standards consist of deuterated compounds covering a wide variety of functional groups (alkanes, alkenes, aldehydes, ketones and polycyclic aromatic hydrocarbons, or PAHs). Periodic calibrations are conducted using a representative range of available organic compounds as external standards. The lists of external and internal standards are summarized in Tables S2 and S3 in the Supplement. While we do not have authentic standards for all the compounds quantified, surrogate standards are assigned in an optimized manner based on similarities in molecular structure. For each compound, its ionization efficiency (and hence, calibration factor) is assumed to be same as that of the assigned surrogate standard. Mass concentration of each compound is obtained by multiplying the observed signal (normalized by signal of the internal standard) by the calibration factor obtained during calibrations. The assignment of surrogate and internal standards is listed in the Supplement. Extraction and analysis of TAG data was performed using custom written code in Igor Pro (Wavemetrics). High-resolution data fitting procedures are adapted from those written for HR-ToF-AMS analysis (DeCarlo et al., 2006) for GC/MS data (Isaacman et al., 2012). Raw time-of-flight data are reconstructed using Gaussian peaks centered at exact masses for a specified list of ions. Ions considered include $\mathrm{C}_{x} \mathrm{H}_{y}^{+}, \mathrm{C}_{x} \mathrm{H}_{y} \mathrm{O}^{+}, \mathrm{C}_{x} \mathrm{H}_{y} \mathrm{O}_{2}^{+}$ (up to $m / z 250$ ) and other inorganic ions (such as $\mathrm{H}_{2} \mathrm{O}^{+}, \mathrm{N}_{2}^{+}$, $\mathrm{O}_{2}^{+}$). Since measurements of highly oxygenated compounds are typically not quantitative with GC/MS, ions containing more than two oxygen atoms are not considered in this analysis.

\subsection{Source apportionment using positive matrix factorization (PMF)}

PMF is used to apportion speciated organic compounds to identify emission and processing sources. PMF is a source apportionment model. The PMF model assumes a linear mixing model, where the observed concentrations of multiple species are a time-varying linear combination of contributions from multiple independent sources with constant composition profiles (Paatero and Tapper, 1994):

$x_{i j}=\sum_{p} g_{i p} f_{p j}+e_{i j}$,

where $x_{i j}$ is the observed concentration of species $i$ at time $j, g_{i p}$ is the contribution of species $i$ to factor $p, f_{p j}$ is the mass concentration of factor $p$ at time $j$ and $e_{i j}$ is the residual error. Each factor $p$ is interpreted to be a group of covarying compounds that originate from the same source or undergo similar transformation processes. The model is solved by minimizing the residual $e_{i j}$ weighted by the measurement precision $\sigma_{i j}$ :

$Q=\sum_{i} \sum_{j}\left(\frac{e_{i j}}{\sigma_{i j}}\right)^{2}$

The objective function $Q$ is minimized using the PMF2 algorithm operated in the PMF2.exe program (Paatero, 2007), and the results are interpreted using the PMF Evaluation Tool (PET) Panel (Ulbrich et al., 2009).

Estimates of measurement precision $\left(\sigma_{i j}\right)$ play an important role in PMF solutions. Here we expect that imprecision in chromatographic peak integration is the dominant source of measurement uncertainty. As a result, we use the range of peak areas calculated for drawing different baselines for peak integration as the standard error used in the model (see Supplement). We treat missing data points using the approach described by Zhao et al. (2013a). For missing data points, we assign a measurement value of one-third the detection limit, and the uncertainty was assigned to be four times that concentration. Only compounds that are above the detection limit more than $50 \%$ of the time were included in PMF analysis. Unlike in previous work (Williams et al., 2010; Zhao et al., 2013a), no attempt is made in this work to reconstruct total organic mass, since, unlike OA, there were no overlapping measurements of total S/IVOC gases.

\subsection{PTR-TOF-MS}

Measurements of selected gas phase species by SVTAG were qualitatively compared to those by protontransfer reaction time-of-flight mass spectrometry (PTRTOF-MS). Details of the instrument and its deployment at 
Table 1. A partial list of compounds measured during BEACHON-RoMBAS 2011. A full list of identified compounds and comparison to literature retention indices are shown in the Supplement.

\begin{tabular}{|c|c|c|c|}
\hline Compound & Retention index & $\begin{array}{r}\text { Median concentration, } \mathrm{ng} \mathrm{sm}^{-3} \\
(10 \text { th-90th percentile) }\end{array}$ & $\begin{array}{r}\text { Median concentration, pptv } \\
\text { (10th-90th percentile) }\end{array}$ \\
\hline \multicolumn{4}{|l|}{ Alkanes } \\
\hline$n$-tetradecane & 1401 & $0.7(0.4-1.3)$ & $0.09(0.05-0.16)$ \\
\hline Branched alkane isomer & 1463 & $0.4(0.3-0.7)$ & $0.05(0.03-0.08)$ \\
\hline$n$-Pentadecane & 1500 & $0.9(0.6-1.3)$ & $0.10(0.07-0.15)$ \\
\hline$n$-Hexadecane & 1600 & $0.9(0.7-1.3)$ & $0.10(0.07-0.14)$ \\
\hline$n$-Heptadecane & 1700 & $0.5(0.3-0.9)$ & $0.05(0.03-0.09)$ \\
\hline Pristane & 1706 & $0.3(0.2-0.4)$ & $0.03(0.02-0.04)$ \\
\hline$n$-Octadecane & 1800 & $0.4(0.2-0.7)$ & $0.03(0.02-0.06)$ \\
\hline$n$-Nonadecane & 1900 & $0.6(0.3-1.0)$ & $0.05(0.03-0.09)$ \\
\hline$n$-Eicosane & 2000 & $0.5(0.3-0.7)$ & $0.04(0.02-0.06)$ \\
\hline$n$-Heneicosane & 2101 & $1.0(0.6-1.4)$ & $0.08(0.05-0.11)$ \\
\hline$n$-Docosane & 2200 & $0.9(0.6-1.5)$ & $0.07(0.05-0.11)$ \\
\hline$n$-Tricosane & 2300 & $1.3(1.0-1.8)$ & $0.10(0.07-0.13)$ \\
\hline$n$-Tetracosane & 2400 & $1.0(0.7-1.3)$ & $0.07(0.05-0.09)$ \\
\hline$n$-Pentacosane & 2500 & $0.5(0.4-0.7)$ & $0.03(0.03-0.04)$ \\
\hline \multicolumn{4}{|l|}{ PAHs } \\
\hline Biphenyl & 1378 & $0.4(0.3-0.7)$ & $0.07(0.05-0.11)$ \\
\hline Naphthalene, 1,6-dimethyl- & 1421 & $0.2(0.1-0.4)$ & $0.03(0.01-0.06)$ \\
\hline \multicolumn{4}{|l|}{ Naphthalene, 1,2,3,4-tetrahydro- } \\
\hline 5,6,7,8-tetramethyl- & 1522 & $0.7(0.4-1.2)$ & $0.10(0.06-0.16)$ \\
\hline Fluorene & 1583 & $0.3(0.1-1.1)$ & $0.05(0.02-0.16)$ \\
\hline Phenanthrene & 1782 & $0.9(0.4-2.4)$ & $0.12(0.06-0.33)$ \\
\hline Anthracene & 1793 & $0.4(0.2-0.5)$ & $0.05(0.03-0.07)$ \\
\hline Fluoranthene & 2066 & $0.4(0.2-0.9)$ & $0.04(0.02-0.10)$ \\
\hline Pyrene & 2119 & $0.3(0.2-0.4)$ & $0.04(0.02-0.05)$ \\
\hline Chrysene & 2470 & $0.7(0.6-0.9)$ & $0.07(0.06-0.09)$ \\
\hline \multicolumn{4}{|l|}{ Oxygenated PACs } \\
\hline Dimethoxybenzaldehyde isomer & 1435 & $0.7(0.3-1.8)$ & $0.10(0.05-0.27)$ \\
\hline Dibenzofuran & 1516 & $1.2(0.5-4.7)$ & $0.17(0.07-0.68)$ \\
\hline Benzophenone & 1630 & $0.2(0.2-0.3)$ & $0.03(0.02-0.04)$ \\
\hline 9H-Xanthene & 1636 & $0.2(0.1-0.7)$ & $0.03(0.01-0.09)$ \\
\hline 9H-Fluoren-9-one & 1739 & $1.0(0.4-3.3)$ & $0.14(0.06-0.45)$ \\
\hline Anthraquinone & 1973 & $0.9(0.5-1.9)$ & $0.10(0.06-0.23)$ \\
\hline \multicolumn{4}{|l|}{ Sesquiterpenes and terpenoids } \\
\hline Longifolene & 1392 & $0.5(0.1-1.1)$ & $0.05(0.02-0.13)$ \\
\hline$\beta$-caryophyllene & 1412 & $1.1(0.3-2.6)$ & $0.13(0.04-0.31)$ \\
\hline Alloaromadendrene & 1470 & $0.8(0.4-1.7)$ & $0.09(0.05-0.20)$ \\
\hline$\beta$-vatirenene isomer & 1471 & $0.4(0.2-0.9)$ & $0.04(0.02-0.11)$ \\
\hline Unknown SQT204 & 1481 & $0.6(0.4-0.8)$ & $0.07(0.05-0.10)$ \\
\hline$\alpha$-Muurolene & 1504 & $0.3(0.1-0.6)$ & $0.03(0.02-0.07)$ \\
\hline Cuparene & 1511 & $1.0(0.5-1.9)$ & $0.12(0.06-0.23)$ \\
\hline Calamenene & 1528 & $3.0(1.2-8.0)$ & $0.36(0.14-0.96)$ \\
\hline Cadina-1(10),6,8-triene & 1593 & $0.3(0.1-0.6)$ & $0.03(0.01-0.07)$ \\
\hline Cadalene & 1680 & $2.2(1.1-5.0)$ & $0.27(0.13-0.61)$ \\
\hline 18-norabieta-8,11,13-triene & 2026 & $0.4(0.2-0.6)$ & $0.03(0.02-0.06)$ \\
\hline \multicolumn{4}{|l|}{ Other oxygenated compounds } \\
\hline Coumarin & 1436 & $0.9(0.6-1.5)$ & $0.14(0.10-0.24)$ \\
\hline Dodecenoic acid isomer & 1536 & $3.0(1.4-6.6)$ & $0.37(0.18-0.81)$ \\
\hline (+)-Longicamphenylone & 1569 & $1.3(0.4-3.3)$ & $0.15(0.04-0.39)$ \\
\hline Tetradecenoic acid isomer & 1737 & $3.1(1.3-6.6)$ & $0.33(0.14-0.71)$ \\
\hline 2-Pentadecanone, 6,10,14-trimethyl- & 1844 & $1.6(1.2-2.4)$ & $0.15(0.11-0.22)$ \\
\hline Hexadecenoic acid isomer & 1941 & $1.7(0.9-4.3)$ & $0.16(0.09-0.41)$ \\
\hline Manoyl oxide & 2004 & $0.5(0.3-0.6)$ & $0.04(0.03-0.05)$ \\
\hline Dehydroabietic acid, methyl ester & 2346 & $0.6(0.3-0.9)$ & $0.04(0.03-0.07)$ \\
\hline
\end{tabular}


BEACHON-RoMBAS are described in a recent publication (Kaser et al., 2013). The PTR-TOF-MS inlet was at a height of $1 \mathrm{~m}$ above ground, and approximately $25 \mathrm{~m}$ away from the SV-TAG inlet horizontally in an area with an uneven distribution of trees. In brief, the PTR-TOF-MS measures a wide variety of VOCs using hydronium ions $\left(\mathrm{H}_{3} \mathrm{O}^{+}\right)$as reagent ions (Graus et al., 2010). In this work, the PTR-TOF-MS measurements at the $1 \mathrm{~m}$ inlet were used for comparison. Owing to the difference in sampling methods and inlet locations, only qualitative comparisons were made for reactive compounds such as sesquiterpenes.

\section{Intermediate and semivolatile organic compounds}

Shown in Fig. 2 is the total ion chromatogram for a representative sample. Since the GC column used is a nonpolar DB5-type column, compounds are separated by volatility, with compounds eluting in the order of decreasing volatility. Organic compounds with volatilities equal to or lower than biphenyl $\left(c^{*}>2 \times 10^{5} \mu \mathrm{g} \mathrm{sm}^{-3}\right.$, where the notation $\mathrm{sm}^{-3} \mathrm{de}$ notes per standard cubic meter at a temperature of $298 \mathrm{~K}$ and pressure of $1 \mathrm{~atm}$ ) are reliably trapped by the focusing trap and can be quantified. We have optimized this system to focus on organic compounds with volatilities ranging between those of tetradecane and pentacosane, whose saturation concentrations, $c^{*}$, are on the order of $1 \times 10^{5}$ and $1 \mu \mathrm{g} \mathrm{sm}^{-3}$, respectively (Pankow and Asher, 2008). Using the procedures described in the previous section, 81 compounds have been tentatively identified as ambient compounds with no detectable signals during blanks. We classify the identified compounds into a few general groups: sesquiterpenes, higher order terpenoids, alkanes, PAHs, oxygenated PAHs, and other oxygenated compounds.

\subsection{Sesquiterpenes $\left(\mathrm{C}_{15} \mathrm{H}_{24}\right.$ and $\left.\mathrm{C}_{15} \mathrm{H}_{22}\right)$}

Sesquiterpenes are known to be emitted from various vegetation (Duhl et al., 2008), including agricultural crops (Ormeño et al., 2010), conifers (Bouvier-Brown et al., 2009b; Helmig et al., 2006), shrubs (Helmig et al., 1999), flowering plants (Chen et al., 2003) and even pathogens (Fravel et al., 2002). Previous studies have focused on sesquiterpenes with molecular formula $\mathrm{C}_{15} \mathrm{H}_{24}$ and molecular weight of $204 \mathrm{amu}$. In this work we refer to these sesquiterpenes as "SQT204". They are highly reactive, with atmospheric lifetimes of less than an hour (Atkinson and Arey, 2003). In addition, owing to their low vapor pressures and multiple rings and double bonds, they are efficient SOA precursors (Lee et al., 2006a, b). Here we are able to separate 7 isomers of SQT204. It is generally difficult to distinguish between different isomers of sesquiterpenes based on mass spectral matching alone, as they fragment strongly upon ionization and have virtually indistinguishable mass spectra. Here we use peaks in three ion traces that are unique to SQT204 $(m / z 204,189,161)$ for peak screening. Longifolene, $\beta$-caryophyllene and alloaromadendrene were identified and confirmed using authentic standards. For all other SQT204, tentative identification was made based on literature retention indices from Adams (2007), and the response factor for these other sesquiterpenes was taken to be the average of those of the 3 SQT204 in our standard. One isomer cannot be positively identified and is labeled as an unknown SQT204. The molecular structures of some SQT204 are shown in Fig. 3.

In general, concentrations of sesquiterpenes are higher at night, which is consistent with local emissions being trapped in a shallow boundary layer, and with slower oxidation at night. The dependence of sesquiterpene emission on sunlight is complex and varies greatly between plant species (Duhl et al., 2008), but is generally weaker than that of isoprene or MBO. It should be noted that sesquiterpene emissions have a positive dependence on temperature (Duhl et al., 2008), but daytime oxidation and boundary dynamics lead to higher observed concentrations at night (Bouvier-Brown et al., 2009a). The diurnal trends are also consistent with the total concentrations of SQT204 measured by PTR-TOFMS (Fig. 4). $\beta$-caryophyllene is the most abundant SQT204 observed, comprising on average $20 \%$ (median) of total SQT204 mass concentrations. This observation is consistent with previous plant enclosure studies, which have identified $\beta$-caryophyllene as a ubiquitous BVOC from many plant species (Duhl et al., 2008; Ormeño et al., 2010). Other SQT204, such as longifolene and $\alpha$-humulene, were also observed, albeit at lower concentrations. It should be noted that a number of sesquiterpenes are more volatile than longifolene (i.e., retention indices $<1400, c^{*}>2 \times 10^{5} \mathrm{\mu g} \mathrm{sm}^{-3}$ ). They are likely to be present but are not reliably measured by this version of our instrument.

While the majority of the signals at SQT204 ions $(m / z 161,189,204)$ are attributed to the speciated SQT204, there remains some signal close to baseline within the elution window for sesquiterpenes (retention indices between 1400 and 1600). We expect this signal to be derived from unspeciated SQT204 that are not baseline-separated by the GC column. To estimate the total concentrations of all SQT204, high-resolution mass spectrometry was used to separate SQT204 ions from other isobars. As an example, $\mathrm{C}_{15} \mathrm{H}_{24}^{+}$, $\mathrm{C}_{14} \mathrm{H}_{20} \mathrm{O}^{+}$and $\mathrm{C}_{16} \mathrm{H}_{12}{ }^{+}$all have the same nominal mass of 204, but only $\mathrm{C}_{15} \mathrm{H}_{24}^{+}$can be produced from SQT204. By applying high-resolution fitting procedures, $\mathrm{C}_{15} \mathrm{H}_{24}^{+}$can be differentiated from other isobars not associated with SQT204. The total $\mathrm{C}_{15} \mathrm{H}_{24}^{+}$signals within the elution window are then integrated to provide an estimate of "total" SQT204 (speciated + unspeciated). The unspeciated SQT204 is taken to have a response factor equal to the average of all 3 SQT204 present in the standard (longifolene, $\beta$-caryophyllene, alloaromadendrene). Similar to the speciated SQT204, the unspeciated SQT204 also show higher concentrations at night and lower concentrations during the day, with daytime con- 


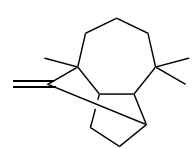

Longifolene (SQT204)

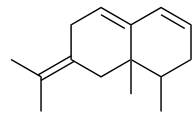

b-vatirenene (SQT202)

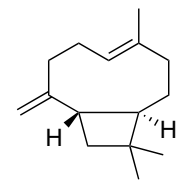

b-caryophyllene (SQT204)

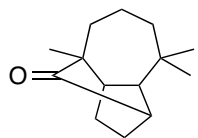

Longicamphenylone

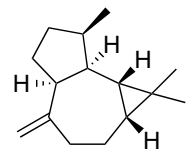

Alloaromadendrene (SQT204)

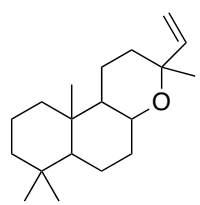

Manoyl oxide

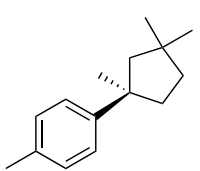

(+)-cuparene (SQT202)

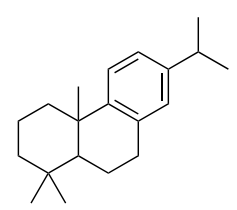

Abietatriene isomer

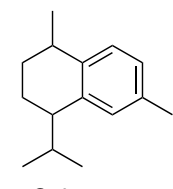

Calamenene (SQT202)<smiles>Cc1cccc2c1ccc1cc(C(C)C)ccc12</smiles>

Retene

Figure 3. Sample terpenoids observed during BEACHON-RoMBAS.
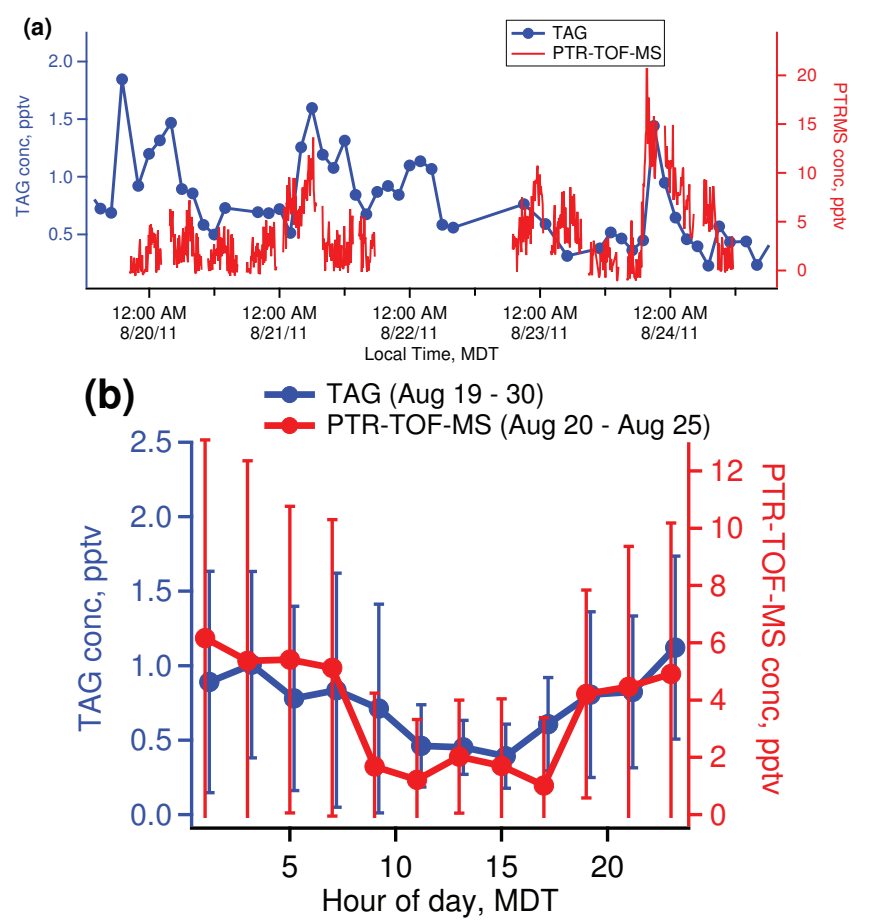

Figure 4. (a) Time series of SQT204 concentration measured by PTR-TOF-MS and by TAG during measurement overlap. (b) Diurnal profile of SQT204 concentration during the entire measurement period of TAG (19-30 August) and PTR-TOF-MS (20 July-25 August). The markers represent the mean concentration and the error bars represent one standard deviation. The general diurnal trends between the two instruments agree qualitatively, but are not expected to be quantitatively consistent owing to different sampling locations.

centrations approximately $40 \%$ lower than nighttime concentrations. This similarity suggests that the speciated and unspeciated SQT204 likely have common sources or reaction sinks.
The concentrations of total (speciated + unspeciated) SQT204 measured by SV-TAG are shown in Fig. 4. The median concentration of total SQT204 is $6.5 \mathrm{ng} \mathrm{sm}^{-3}$, or 0.7 pptv. As Fig. 4 shows, the diurnal trend correlated well with that of PTR-TOF-MS measurements throughout the full campaign (20 July-25 August). Also, the rise and fall in concentrations on 23-24 August are well captured by most measurements. The time trends of the two sets of measurements are therefore qualitatively consistent, but it is not expected that they will agree quantitatively due to the different sampling locations (both vertically and horizontally). As noted previously, the SV-TAG inlet was at a height of $4 \mathrm{~m}$ above ground, while the nearest PTR-TOF-MS inlet was at a height of $1 \mathrm{~m}$ above ground, and the inlets were approximately $25 \mathrm{~m}$ apart horizontally in an area with an uneven distribution of trees. There is expected to be strong vertical gradients in sesquiterpene concentrations, since active oxidation by ozone within canopy has been inferred from significant vertical and temporal gradients in ozone concentrations at similar sites (Goldstein et al., 2004; Kurpius and Goldstein, 2003; Park et al., 2014; Jardine et al., 2011), and should be strong horizontal gradients as a function of distance from the source. Also, no attempt was made to remove ozone from the SV-TAG filter cell since ozone denuders (such as $\mathrm{NaS}_{2} \mathrm{O}_{3}$-impregnated honeycombs) will likely remove other S/IVOCs. We cannot exclude losses of sesquiterpenes adsorbed on to the SS fiber filter in the SV-TAG instrument due to surface assisted ozonolysis during sampling. There may also be some SQT204 more volatile than longifolene that are not reliably captured by the focusing trap, leading to underestimation of total SQT204 concentrations by SVTAG. To the authors' best knowledge, this is the first work comparing speciated SQT204 measurements with total SQT measurements by PTR-TOF-MS. Since the diurnal trends of SQT204 are consistent between the two measurement techniques and with expected dependence on boundary layer dynamics and oxidation chemistry, SQT204 concentrations measured by SV-TAG reported here are taken to be lower 
limits and the time trends are representative of those of total SQT204. These measurements will be used to understand the sources and assess the contribution of SQT204 to local chemistry. However, further work should focus on reconciling the difference in absolute measurements between these two techniques using co-located measurements.

It has been reported that sesquiterpene emissions can increase significantly from mechanical disturbances (Arey et al., 1995; Goldstein et al., 2004). There were no significant precipitation or violent weather events during the 10-day measurement period presented here. Our measurements extend beyond the official end of the field campaign on $25 \mathrm{Au}-$ gust 2011, during which many instruments were transported out of the field site; however, no spikes in concentrations were observed during that day, and the highest concentrations were observed at night when traffic was the lowest. Therefore our observations are not thought to be influenced by spikes in concentrations caused by researchers' activities (such as plant enclosure setup) that are likely smoothed out with the $2 \mathrm{~h}$ time resolution. Therefore we expect the observed variability in concentrations to depend most strongly on meteorology and oxidation chemistry.

In addition to SQT204, we also observed a variety of sesquiterpenes with molecular formula of $\mathrm{C}_{15} \mathrm{H}_{22}$. Their molecular weights are $202 \mathrm{amu}$ and are hereafter referred to as "SQT202". Compared to the better-known SQT204, this group of compounds likely has an additional double bond or ring. Also, they have lower volatilities as they have longer retention times in the GC column. Some isomers, such as cuparene and calamenene, contain an aromatic ring, while others, such as $\beta$-vatirenene, do not. Some proposed molecular structures are shown in Fig. 3. A few SQT202 isomers cannot be positively identified. These unidentified isomers all have strong signals at ions characteristic of SQT202 $(\mathrm{m} / \mathrm{z} 202$, $187,159)$ and have mass spectra matching very well to the same SQT202 entry in the mass spectral libraries (e.g., $\beta$ vatirenene). Their retention times do not match any known SQT202 in the literature. We have named them " $\beta$-vatirenene isomer", recognizing that these peaks are unknown isomers of $\beta$-vatirenene or other SQT202.

The source of these SQT202 is likely biogenic, since they are known to be present in essential oils (Adams, 2007). To the authors' best knowledge, this is the first study to report observations of SQT202 in the ambient atmosphere. One study has shown that cuparene is emitted by Arabidopsis flowers during pollination (Chen et al., 2003). Calamenene has also been identified in plant enclosure studies in a tropical forest (Pankow et al., 2012) and from soil borne plant pathogens (Fravel et al., 2002). Since we did not have authentic standards for SQT202 during the field measurements, we use the 3 SQT204 present in our standard (longifolene, $\beta$-caryophyllene and alloaromadendrene) as surrogate standards for quantification of all SQT202. A post-campaign calibration was conducted on a similar HR-ToF mass spectrometer using electron impact ionization (Chan et al., 2013), and the response factors for a few $\mathrm{C}_{15} \mathrm{H}_{22}$ isomers were found to be within $20 \%$ of the SQT204 sesquiterpenes in the injection standard.

Similar to SQT204, the observed SQT202 concentrations are higher at night and lower during the day, which is consistent with local emission sources and a dependence on boundary layer dynamics and oxidation rates. Calamenene and cuparene are the most abundant SQT202. The total concentration of SQT202 was estimated using the same high-resolution fitting procedures as described for SQT204. The total concentration of SQT202 (1-23 ng sm ${ }^{-3}$, or $0.1-$ $2.8 \mathrm{pptv})$ is comparable to that of SQT204 $\left(0-19 \mathrm{ng} \mathrm{sm}^{-3}\right.$, or 0-2.3 pptv). The volatilities of SQT202 are expected to be lower than those of SQT204, since they elute later from the GC column. Using the observed concentrations of SQT204 and SQT202 reported here as lower limits, we estimate the $\mathrm{OH}$ and ozone reactivities of these species at Manitou Forest (see Sect. S14 in the Supplement). While the contribution to $\mathrm{OH}$ reactivity is negligible, sesquiterpenes can dominate ozone reactivity in the forest over other emitted species, such as monoterpenes and $\mathrm{MBO}$, owing to higher rate constants.

\subsection{Higher order terpenoids and other biogenic compounds}

A number of compounds with diterpenoid backbones were also observed in the atmosphere. They contain three fused six-membered rings with an isopropyl group, which is the same backbone as abietic acid and isopimaric acid. These acids are the primary components of wood resin, and are used as a chemical defense against insect and pathogenic fungi and bacteria (Dewick, 1997). Among these diterpenoids are norabietanes, abietanes, retene and methyl-retenes. These compounds all have the abietane structures but contain fewer than 20 carbon atoms. They have often been used as particle tracers of softwood combustion, which volatilizes the resin and releases these compounds into the atmosphere ( $\mathrm{Si}$ moneit, 2002). However, the observed concentrations did not correlate with PTR-TOF-MS measurements of acetonitrile, a frequently used biomass burning tracer (Holzinger et al., 1999; de Gouw and Warneke, 2007). Temporal variations in concentrations of diterpenoids were consistent from one day to another, with concentrations peaking at night and decreasing during the day. We did not observe any sudden changes in concentrations, which one would expect from local fire plumes. The diurnal trends of these compounds are similar to those of sesquiterpenes mentioned earlier, suggesting they are directly emitted from the local vegetation rather than from biomass burning.

Some oxygen-containing biogenic compounds were also observed. These include longicamphenylone, manoyl oxide, coumarin, dehydroabietic acid methyl ester and benzophenone. Many of these compounds are found in essential oils or plant extracts and were identified based on matching to essential oil mass spectral database (Adams, 2007). At the 
same time, longicamphenylone may also be a reaction product of longifolene and ozone (Isaacman et al., 2011b). Based on correlation of time series alone, the relative contributions of primary and secondary sources cannot be definitively identified. Manoyl oxide has also been previously observed in the Finnish coniferous forest (Anttila et al., 2005). It should be noted that many secondary products of monoterpene oxidation (such as verbenone, pinonaldehyde etc.) have volatilities greater than that of $n$-tetradecane, or are too oxidized to elute from the GC column, and therefore would not be measured by this instrument.

\subsection{Alkanes}

Alkanes ranging from $\mathrm{C}_{14}$ to $\mathrm{C}_{25}$ were also observed during the field campaign. All of the observed $n$-alkanes were quantified using authentic standards. Two branched alkanes, pristane and phytane, were also observed and quantified. Pristane and phytane are commonly associated with petrogenic sources, and have often been used as tracers for diesel exhaust in urban air quality studies (Rogge et al., 1993). Other alkanes in this volatility range are also emitted from incomplete combustion of fossil fuels (Gentner et al., 2012). While plant wax is expected to contribute a large amount of $\mathrm{C}_{27}$, $\mathrm{C}_{29}$ and $\mathrm{C}_{31} n$-alkanes (Eglinton et al., 1962), they were not measured in the deployed version of our instrument because they were below the targeted volatility range. Among the $n$ alkanes, $\mathrm{C}_{14}-\mathrm{C}_{14}$ and $\mathrm{C}_{21}-\mathrm{C}_{23} n$-alkanes are the most abundant, with median concentrations around $1 \mathrm{ng} \mathrm{sm}^{-3}$ for each alkane.

In the extracted ion chromatograms for alkane ions $(m / z 43,57,71)$, there is an observed "hump" of unresolved compounds. This group of hydrocarbons, commonly known as the unresolved complex mixture (UCM), is comprised of a large number of branched and cyclic hydrocarbon isomers (Chan et al., 2013). The UCM is a common feature of petrogenic mixtures, such as diesel and motor oil, suggesting that anthropogenic activities contributed petrogenic S/IVOCs at this site. At the end of the field campaign, moving trucks for other field instruments did not appear to cause significant increases in $n$-alkane or UCM signals on 25 August 2011. We therefore expect that the observed variability in alkane signals (on $2 \mathrm{~h}$ timescales) is derived from a regional source and the contribution from local emissions is relatively small.

Semivolatile $n$-alkanes have also been observed at other forest sites. Filter samples collected at a Scots Pine forest in Finland showed individual $n$-alkane concentrations around $0-10 \mathrm{ng} \mathrm{m}^{-3}$ for $\mathrm{C}_{11}$ to $\mathrm{C}_{28} n$-alkanes (Rissanen et al., 2006). It should be noted that the SV-TAG cell has a significantly larger surface area than quartz filters for adsorption of organic vapors (Zhao et al., 2013b) and the collection is reproducible, distinguishing these measurements from observed partial adsorption onto traditional filters. The potential sources of alkanes at this field site will be discussed later in this manuscript.

\subsection{PAHs and PACs}

In addition to $n$-alkanes, polycyclic aromatic hydrocarbons (PAHs) and other polycyclic aromatic compounds (PACs) were also observed at this field site. Many of these compounds are positively identified with authentic standards, and other PAHs are identified with great certainty using mass spectral and retention time matching, given the tendency of these species to present a strong molecular ion upon EI ionization. The most volatile PAH observed was dimethylnaphthalene, and chrysene was the least volatile PAH observed. Other PACs include oxygen-containing compounds and 2 sulfur-containing compounds (dibenzothiophenes).

Phenanthrene, chrysene and biphenyl are the most abundant PAHs, with median concentrations of $0.9,0.7$, and $0.4 \mathrm{ng} \mathrm{sm}^{-3}$ (or $0.12,0.07$, and $0.07 \mathrm{pptv}$ ), respectively. The total concentrations of identified PAHs range from 6.2 to $16.2 \mathrm{ng} \mathrm{sm}^{-3}$ (10th-90th percentile). The most abundant PACs are oxygen-containing compounds (anthraquinone, 9(H)-fluorenone and dibenzofuran) with median concentrations around $1 \mathrm{ng} \mathrm{sm}^{-3}$ or $0.1 \mathrm{pptv}$. PAHs and PACs are generally more abundant during the day, exhibiting a different diurnal trend from the locally emitted sesquiterpenes (see Fig. S11 in the Supplement). PACs are frequently associated with incomplete combustion and their potential sources will be discussed later in the manuscript.

\section{Total mass and volatility distribution}

One of the key factors controlling SOA formation is precursor and product volatility (Pankow, 1994). The distribution of organic compounds in the S/IVOC range is poorly known, but is important for modeling organic aerosol and gas evolution. Here the volatility distribution of eluted organic compounds can be constructed from the total ion chromatograms, since GC retention time, $t_{\mathrm{R}}$, is related to volatility. $N$-alkanes are linearly spaced in retention time, and, using their known vapor pressures, the total organic signal is grouped into bins of $n$-alkane-equivalent volatilities. To estimate the total mass of organic compounds eluting from the column at a given retention time, the high-resolution mass spectrometry data were used. We restrict our analysis to only hydrocarbon-like ions $\mathrm{C}_{x} \mathrm{H}_{y}^{+}$, which are most amenable to $\mathrm{GC}$ analysis. The calibration factor used to convert $\mathrm{C}_{x} \mathrm{H}_{y}^{+}$ion signal to organic mass is calculated from the average calibration factor derived from external standard calibrations. Based on the range of calibration factors obtained for the different external standards, this method is expected to be accurate to $\pm 40 \%$.

The median volatility distribution of hydrocarbons is shown in Fig. 5. The total gas-phase concentration of hydrocarbon-like species with volatilities between that of tetradecane and hexacosane is approximately $0.7 \mu \mathrm{g} \mathrm{sm}^{-3}$, a factor of 3-4 lower than the total amount of organic aerosol (an average of $2.5 \mu \mathrm{g} \mathrm{sm}^{-3}$ ) measured by the AMS 


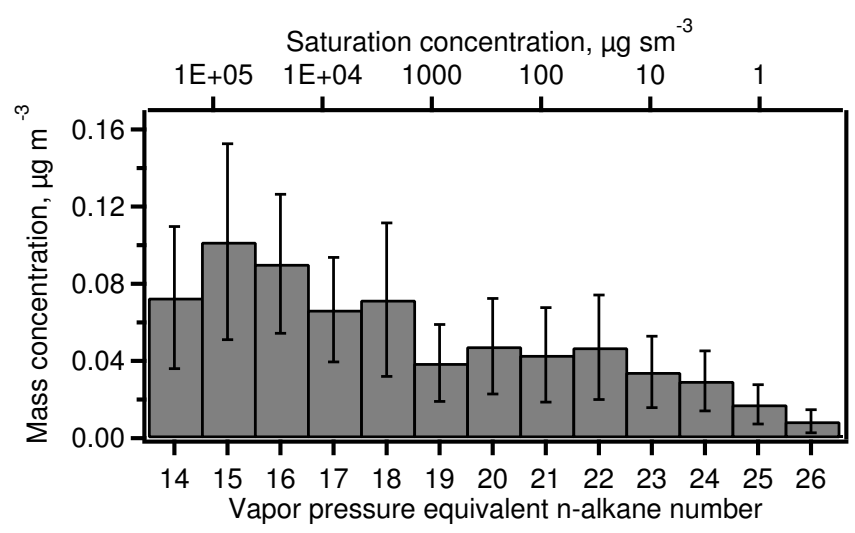

Figure 5. Average volatility distribution of total hydrocarbons observed by SV-TAG. The whiskers represent the standard deviation of the measurements. The volatility distribution was calculated using fitting of high-resolution mass spectrometry data, and the vapor pressures are estimated from retention times of $n$-alkanes.

(Ortega et al., 2014). The mass concentration of hydrocarbons generally decreases with volatility, except in the range of $\mathrm{C}_{19}-\mathrm{C}_{23}$, which is consistent with the UCM observed from the total ion chromatogram. It should be noted that typically without derivatization, less than $50 \%$ of the total organic mass elute from the GC column (Rogge et al., 1993). The remaining gas-phase organic mass is likely comprised of oxidized products that do not elute from the GC column. The fraction of elutable organic material is likely even lower in more biogenically influenced environments, where S/IVOCs are likely more oxidized. To improve recovery of oxygenated compounds from the GC for better estimation of organic mass and volatility distribution, derivatization of oxygenated compounds is likely needed and have been incorporated into future designs of TAG-AMS (Isaacman et al., 2014).

\section{Source apportionment of S/IVOCs: positive matrix factorization}

PMF was used to help determine the sources of S/IVOCs measured by the SV-TAG. The optimum number of factors was chosen based on interpretability of factors, and a threefactor solution was determined with fPEAK (a tool to explore rotation of solutions) of 0 . The value of $Q / Q_{\exp }$ (objective function for minimization) was equal to 2.32 , indicating that the error estimates used in the PMF solution were reasonable (Ulbrich et al., 2009). As recommended by U1brich et al. (2009), two-factor and four-factor solutions were also explored. The four-factor solution splits factor 1 (biogenic I/SVOCs) into two factors composed of different compounds. The correlations with external tracers were found to be quite similar, suggesting that although the factors contain different compounds, they likely represent the same sources. In the two-factor solution, factors 2 and 3 (from the three- factor solution) are convolved. These factors have different time profiles, with factor 2 dominating in the first half of the measurement period, and factor 3 rising in contribution towards the latter half. The difference in time profiles suggests two different sources. A three-factor solution is therefore chosen.

The physical interpretation of the factors is first evaluated by examining the organic species associated with the factor (shown in Fig. 6), which provides chemical information about the source type and/or atmospheric processes represented by the factor. The diurnal profiles, wind rose profiles (shown in Fig. 7), back trajectory analyses (Fig. 8) and correlations with TAG measurements (Table S4) and other measurements (Fig. 9), such as aerosol species and trace gases, are then used to support the interpretations.

\subsection{Factor 1: biogenic S/IVOCs}

This factor is primarily composed of biogenic compounds, including both SQT202 and SQT204, diterpenes, and many of their structural analogs. The oxygenated compounds found in this factor include coumarin, longicamphenylone and manoyl oxide. While these compounds are potentially atmospheric oxidation products, they are also found in plant oil extracts and are potentially primary emissions (Adams, 2007). Given the high correlation of this factor with the concentrations of primary biogenic hydrocarbons, this factor therefore represents primary biogenic emissions of I/SVOCs. It is also likely that the fast reactions of sesquiterpene with ozone led to the grouping of reaction products with its precursors. The factor diurnal profile also follows that of monoterpenes. The factor is highest during the night and lowest during the day, consistent with daytime dilution in the boundary layer and destruction by photochemical reactions.

Factor 1 also has the strongest anticorrelation with wind speed $(r=-0.5)$, suggesting that the concentrations build up as a result of local emissions when mixing is at its minimum. The wind profile of factor 1 , which indicates the average factor signal for each wind direction (in $30^{\circ}$ bins), is shown in Fig. 7. Factor 1 is highest when the winds are coming from the pine forests to the west of the field site. As noted earlier, wind from that wind sector tends to be dominant during nighttime when the boundary layer is shallow. Back trajectory analysis was conducted using HYSPLIT to investigate the history of the air masses arriving at the field site (Draxler and Rolph, 2013). Two periods during which factor 1 shows the strongest signal were chosen (see Fig. 8, trajectories 1 and 4). These two periods represented pristine air arriving from the high-altitude forests from the west, carrying biogenic emissions to the field site.

Factor 1 also shows strong correlations with measurements of other primary biogenic species. It is most correlated with monoterpenes $(r=0.41)$, sesquiterpenes $(0.51)$ and methanol (0.36) measured by the PTR-TOF-MS. The correlation with secondary species, such as acetaldehyde and 


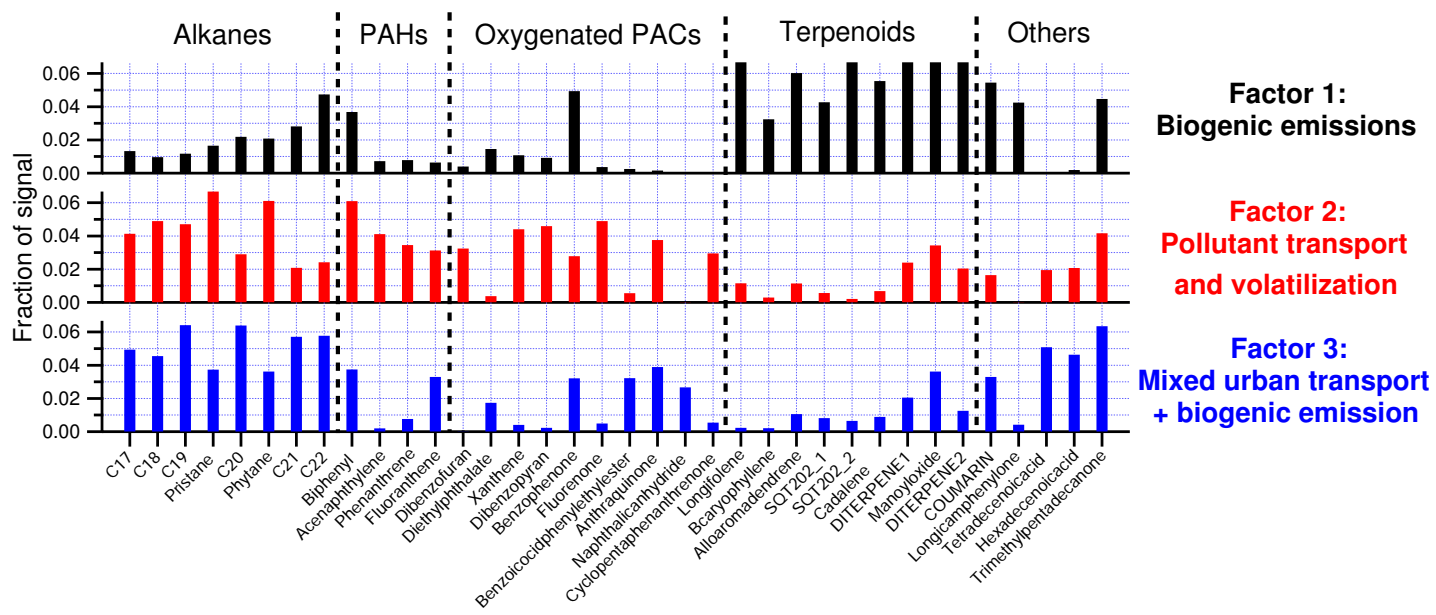

Figure 6. Factor profile of the three-factor solution using PMF. Factor 1 contains many biogenic terpenoids, while factor 2 is mainly comprised of anthropogenic pollutants such as PAHs and PACs. Factor 3 may represent a mixed source of anthropogenic and biogenic compounds.

methacrolein/MVK is weaker, since these oxidation products are formed during the day, when factor 1 is lowest. Similarly, MBO and isoprene emissions are strongly dependent on sunlight and temperature, and, as a result, their concentrations are typically higher during the day, despite the deeper boundary layer (Ortega et al., 2014). As a result, there is no positive correlation with the factor 1 signal $(r=-0.18)$. Factor 1 is also strongly correlated with relative humidity and anticorrelated with temperature, likely owing to the higher concentrations of biogenic species at night when the temperature is low and RH is high. As discussed earlier, wood burning is not expected to be the source of these species, since factor 1 is not correlated with acetonitrile $(r=-0.53)$, a commonly used biomass-burning tracer.

Moving to a four-factor solution splits this biogenic factor into two: one factor contains two more volatile sesquiterpenes (longifolene and $\beta$-caryophyllene), while the other factor is composed of the other biogenic compounds. There may be subtle differences in sources and sinks between these two SQT204 and other biogenic compounds, but the physical meanings of the two factors cannot be distinguished at this point, since their correlations with external tracers are very similar. Using a longer measurement period with more samples, one could potentially identify two different sources or sinks in this area: one for the emissions of longifolene and $\beta$-caryophyllene and the other for SQT202 and higher order biogenic compounds.

\subsection{Factor 2: temperature-dependent volatilization and urban transport of S/IVOCs}

Factor 2 contains many known anthropogenic compounds, in particular PAHs and PACs (cf. Table S4). The correlation coefficient $r$ ranges between 0.66 (methylanthracene) and 0.91 (fluorene) for PAHs and 0.73 (methyl-dibenzothiophene) and 0.96 (methyl-dibenzofuran) for oxygenated PACs. However, other oxygenated PACs, such as anthraquinone and naphthalic anhydride, have a higher correlation with factor 3. Interestingly, although factor 2 contains many alkanes, the correlation coefficients are significantly lower than those for PAHs, ranging from 0.3 ( $n$-tetradecane) to $0.75(n$ octadecane). The exceptions are pristane and phytane, which are generally considered petroleum markers and are indicative of vehicular emissions (Rogge et al., 1993). These two compounds are grouped into factor 2, with $r$ of 0.79 and 0.78 , respectively. The correlation of factor 2 with biogenic compounds is negative in some cases and weak in others.

Given the strong correlation with anthropogenic compounds and poor correlation with biogenic compounds, this factor is most likely associated with anthropogenic pollutants in the area. The field site is situated in a forest with very limited nearby traffic or combustion emissions, and unlike the locally emitted terpenoid compounds in factor 1 , factor 2 reaches its maximum during the day and minimum at night (Fig. 7). Interestingly, although this factor contains mostly anthropogenic PAHs and PACs, its diurnal profile is somewhat different from that of trace gas pollutants, such as $\mathrm{CO}, \mathrm{SO}_{2}$ and $\mathrm{NO}_{x}$. Factor 2 begins to rise at around 10:00, reaches its maximum around early afternoon, and drops after 20:00. $\mathrm{CO}, \mathrm{NO}_{x}$ and $\mathrm{SO}_{2}$ also rise at around 10:00, but peak later in the afternoon and do not drop until after 20:00 (see Fig. S11). Instead, factor 2 has the highest correlation with ozone and temperature. The strong positive correlation with temperature suggests that a temperature-dependent volatilization process governs the variability of PAHs and PACs. Figure S12 shows the Clausius-Clapeyron plot of a few PAHs and PACs in factor 2. The enthalpy for volatilization $\left(\Delta H^{*}\right)$ of each compound is derived from the slope of its Clausius-Clapeyron relation. For compounds that are associated with factor 2 , the derived $\Delta H^{*}$ range between 20 and 
Factor 1: Biogenic emissions
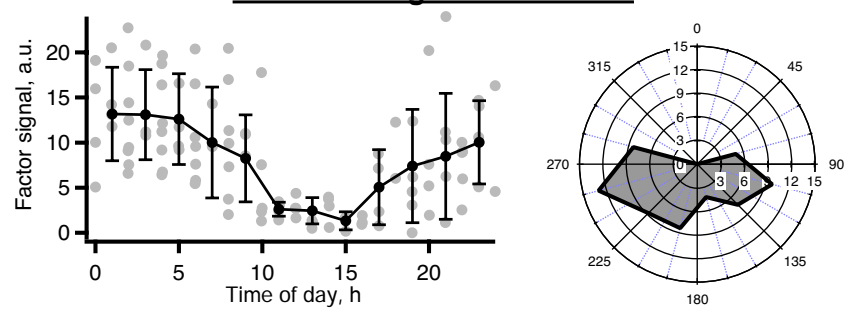

Factor 2: Pollutant transport + volatilization
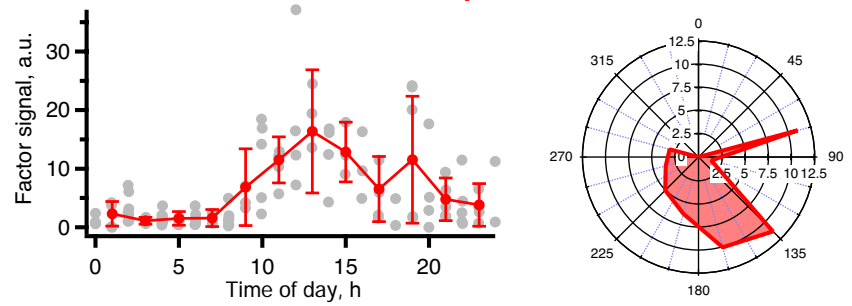

Factor 3: Mixed urban transport + biogenic emission
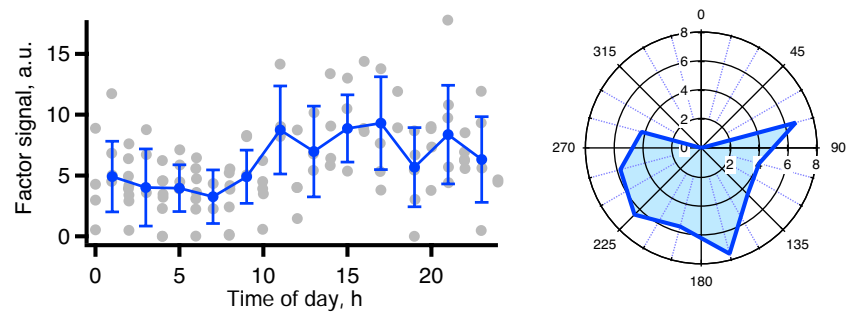

Figure 7. PMF factor wind and diurnal profiles. For each factor, the grey markers represent factor signals for the entire sampling period (grouped by hour of day); the dark line and markers represent diel averages, and the error bars represent one standard deviation. The wind profiles are average factor signals grouped by average wind directions. Factor 1 is strongest during the night and during transport from forests to the west and south of the field site, consistent with local biogenic emissions. Factor 2 appears to be strongest during the day, and likely originates from a temperature-dependent volatilization process (see Fig. S12). It may also represent compounds transported from developed areas to the east. Factor 3 appears to be have mixed sources.

$80 \mathrm{~kJ} \mathrm{~mol}^{-1}$ (see Table S13). For compounds where literature values are available (Bamford et al., 1999; Chickos and Hanshaw, 2004; Roux et al., 2008), these values are generally lower than experimental enthalpies of vaporization, $\Delta H_{\mathrm{vap}}$, but are remarkably consistent with Henry's law enthalpies $\left(\Delta H_{\mathrm{H}}\right)$. Our $\Delta H^{*}$ values are also consistent with those derived from 2 years of field measurements in the Athabasca oil sands region (Hsu et al., 2015). The agreement with Henry's law enthalpies suggests that factor 2 represents SVOCs partitioning between the atmosphere and sources such as bodies of water or soil, and their atmospheric concentrations are determined by temperature-dependent volatilization. Lower values of $\Delta H^{*}$ can also be a result of long-range transport, which reduces the apparent dependence of concentrations on (a)

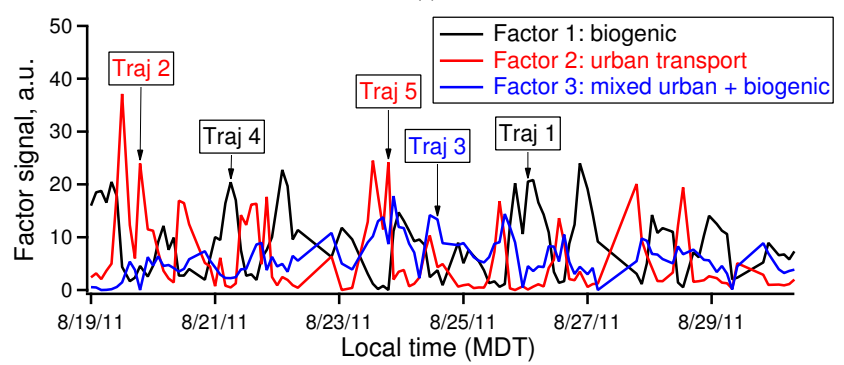

(b)

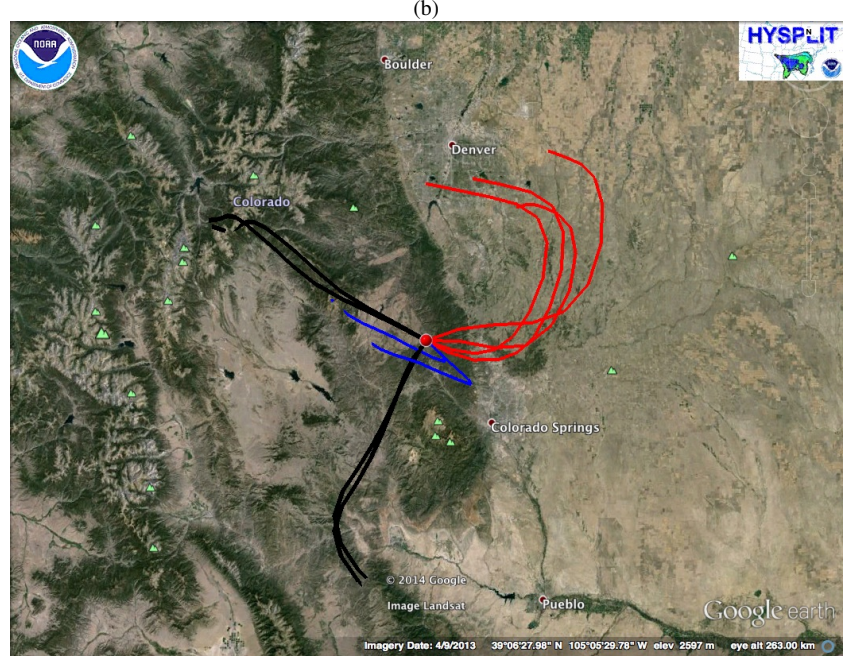

Figure 8. (a) Time series of PMF factor signals. Also denoted in the graph are the periods for which HYSPLIT back trajectories are calculated. (b) $12 \mathrm{~h}$ back trajectories calculated using HYSPLIT (Draxler and Rolph, 2013).

temperature and shallower slope in the Clausius-Clapeyron plot (Wania et al., 1998).

The role of transport in factor 2 is also suggested by its positive correlation with wind speed (0.50). This factor has the highest loading when the wind direction is SE or NE (Fig. 7). This factor can therefore be associated with the upslope flow from the east, carrying urban pollutants up the valley to the field site. Back trajectory analysis using HYSPLIT shows that during two periods when factor 2 contribution is high, the air masses arriving at the field site had travelled from the Denver metropolitan area upslope to the field site (Fig. 8, trajectories 2 and 5). Therefore, the source of S/IVOCs in factor 2 is a combination of volatilization from secondary sources (soils, bodies of water) and transport from nearby urban areas.

While factor 2 appears to have a positive correlation with acetonitrile $(0.48)$, it has a poor correlation with $f_{60}$ measured by AMS, a common tracer of fresh biomass burningrelated organic aerosol (Schneider et al., 2006; Cubison et al., 2011), even after accounting for background signal of $m / z 60$ from aged SOA by subtracting $0.3 \%$ of OA from the $m / z 60$ signal (Cubison et al., 2011). The trends in factor signal are 

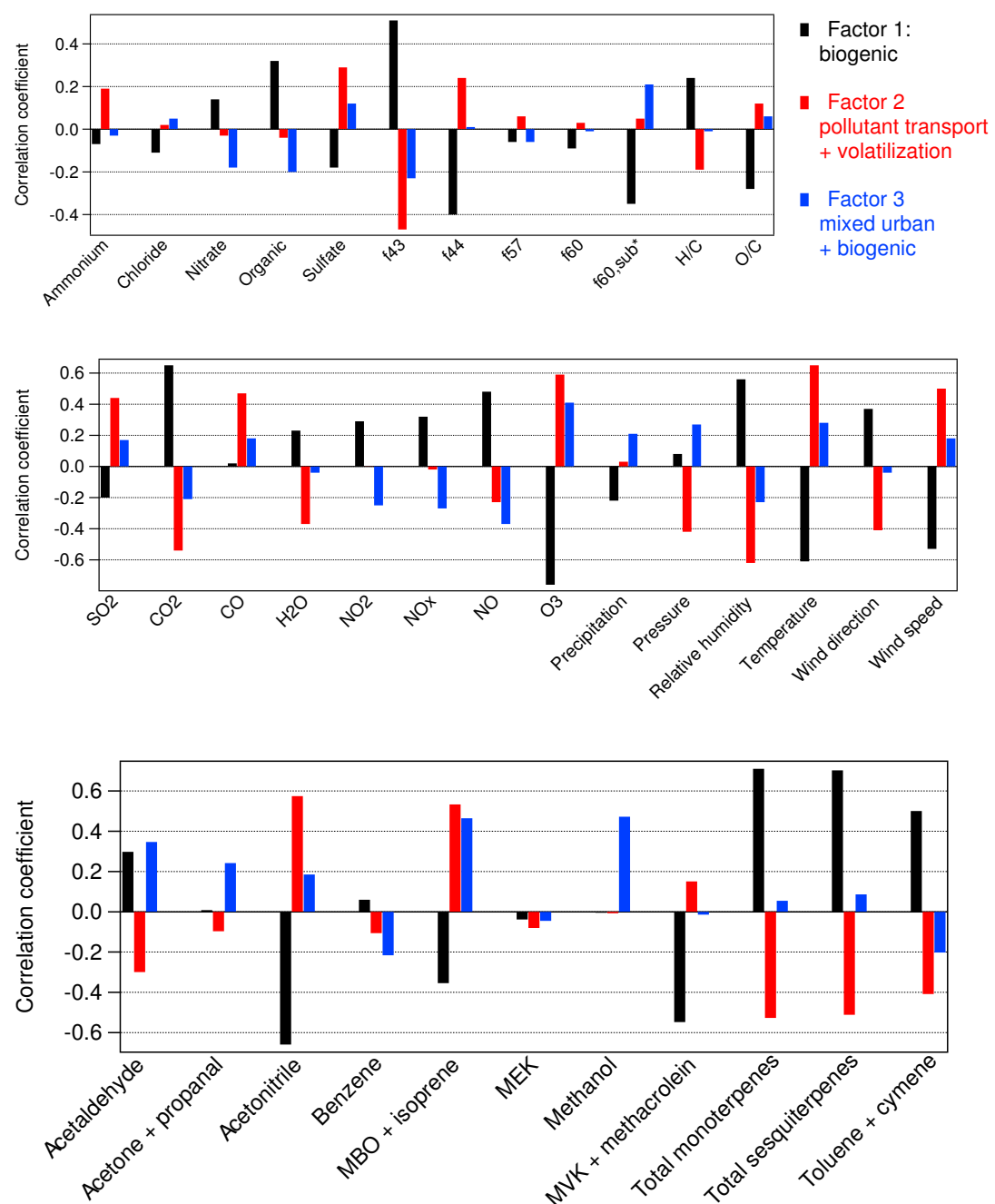

Figure 9. Correlation coefficients $(r)$ of PMF factors with (a) aerosol species measured by the standalone AMS, (b) trace gas measurements and meteorological parameters, and (c) volatile organic compounds measured by PTR-TOF-MS. Correlation coefficients of PMF factors with TAG compounds are shown in Table S4. $f_{60 \text {, sub }}$ refers to the fraction of $m / z 60$ after subtraction of background SOA (0.3\% of AMS organic concentration).

also quite consistent from one day to another, suggesting that it is unrelated to sporadic fire events (forest fire or campfires). Given the temporal trend, the correlation with acetonitrile could imply minor contribution from aged wood smoke.

\subsection{Factor 3: mixed urban transport and biogenic emissions}

Factor 3 may share a similar source as factor 2, since the two-factor solution combines these two factors, and their diurnal profiles are similar, with minimum concentrations occurring at night. However, the differences between daytime and nighttime concentrations are smaller than that for factor 2. The correlations between factor 3 and anthropogenic tracers, such as $\mathrm{CO}$ and $\mathrm{SO}_{2}$, while positive, are generally weak $(r<0.3)$. Therefore, although factor 3 has contributions from urban emissions, the source of the S/IVOCs or the transport processes are likely different from those of factor 2 . In the compound profiles, factors 2 and 3 both contain $n$ alkanes and some PACs. The two factors differ in PAHs, most of which are correlated with factor 2 but not with factor 3 . Instead, factor 3 is correlated with oxygenated compounds such as tetradecenoic acid, anthraquinone and two phthalates. Anthraquinone and naphthalic anhydride are likely to be secondary oxidation products, and phthalates have long atmospheric lifetimes. Therefore we hypothesize that factor 3 represents anthropogenic S/IVOCs that have undergone longerrange transport and thus further oxidation than those associated with factor 2 , and are likely part of the regional background signal.

In addition, factor 3 has stronger contributions from many $n$-alkanes than factor 2 . The $n$-alkanes associated with factor 3 are unlikely to be petrogenic, since pristane and phy- 
tane are not associated with factor 3 . The high correlations with alkenoic acids are notable, with strong correlations with tetradecenoic acid $(r=0.60)$ and hexadecenoic acid $(r=$ $0.64)$. Plant wax contains even-numbered $n$-alkenoic acids and odd-numbered $n$-alkanes, which can be emitted into the atmosphere (Rogge et al., 1993). The back trajectory of an air mass arriving when factor 3 is strong suggests a mix of rural air (carrying long-lived biogenic compounds) with air from more developed areas to the east (with anthropogenic pollutants). We therefore hypothesize that in addition to the regional background, there may be some contribution from plant wax emissions to this factor. The biogenic compounds in factor 3 have longer atmospheric lifetimes than sesquiterpenes, and can therefore be mixed with the regional background signal.

\section{Conclusions}

In this work, we present speciated, highly time-resolved measurements of semivolatile and intermediate volatile organic compounds in the high-altitude pine forest. The chemical composition is complex, consisting of more than 80 compounds spanning 5 orders of magnitude in volatility. Several of these compounds were discovered in the ambient atmosphere for the first time, including sesquiterpenes with molecular formulas of $\mathrm{C}_{15} \mathrm{H}_{22}$ and higher order terpenoids. We conclude these compounds are derived from plant emissions since they have previously been identified in plant oil extracts. Statistical analysis using PMF provides further evidence, as their wind and diurnal profiles are consistent with local emissions from the forest. Future laboratory experiments should focus on understanding the atmospheric kinetics of newly discovered compounds, such as cuparene and calamenene.

Anthropogenic compounds are also found to be significant at this rural site. While it is often assumed that observed pollutants are transported from urban areas, our results show that the local concentrations of anthropogenic SVOCs, such as PAHs and alkanes, are also influenced by volatilization processes from local reservoirs. Many SVOCs are expected to be efficient SOA precursors, but such evaporation processes have not been studied in detail and not included in current models. The urban influence has also been demonstrated for other pollutants at this field site, such as $\mathrm{NO}_{x}$ and $\mathrm{SO}_{x}$ (Fry et al., 2013; Ortega et al., 2014). The interactions between anthropogenic pollutants and biogenic hydrocarbons have been proposed to be a significant source of global secondary organic aerosol (Carlton et al., 2010; Hoyle et al., 2011; Spracklen et al., 2011). For example, oxidation of MBO (a biogenic hydrocarbon) in the presence of sulfate aerosol (an anthropogenic pollutant) leads to formation of MBO-organosulfate, which has been observed at this site (Zhang et al., 2012). More speciated measurements of biogenic and anthropogenic hydrocarbons and their oxidation products are needed to study these biogenic-anthropogenic interactions.

\section{The Supplement related to this article is available online at doi:10.5194/acp-16-1187-2016-supplement.}

Acknowledgements. The authors would like to acknowledge funding from the National Science Foundation (Rapid Award Number 1135745), Department of Energy (SBIR Award Number DE-FG02-08ER85160) and the Austrian Science Fund (FWF project number L518-N20). The authors would like to thank Andrew Turnipseed for use of trace gas and meteorological measurements and Brett Palm, Amber Ortega, and Patrick Hayes for use of AMS measurements. The authors would also like to thank Jim Smith, John Ortega, and NCAR for organizing the logistics of BEACHON-RoMBAS 2011. P. Campuzano-Jost, D. A. Day, and J. L. Jimenez were supported by NSF AGS-1243354, NOAA NA13OAR4310063, and DOE(BER/ASR) DE-SC0011105. L. Kaser is a recipient of a DOC-fFORTE Fellowship of the Austrian Academy of Science.

Edited by: J. Rinne

\section{References}

Adams, R. P.: Identification of Essential Oil Components by Gas Chromatography Mass Spectrometry, 4th edn., Allured Publishing Corporations, Carol Stream, IL, USA, 2007.

Anttila, P., Rissanen, T., Shimmo, M., Kallio, M., Hyötyläinen, T., Kulmala, M., and Riekkola, M.-L.: Organic compounds in atmospheric aerosols from a Finnish coniferous forest, Boreal Environ. Res., 10, 371-384, 2005.

Arey, J., Crowley, D. E., Crowley, M., Resketot, M., and Lester, J.: Hydrocarbon emissions from natural vegetation in California's South Coast Air Basin, Atmos. Environ., 29, 2977-2988, 1995.

Atkinson, R. and Arey, J.: Atmospheric degradation of volatile organic compounds, Chem. Rev., 103, 4605-4638, doi:10.1021/cr0206420, 2003.

Bamford, H. A., Poster, D. L., and Baker, J. E.: Temperature dependence of Henry's law constants of thirteen polycyclic aromatic hydrocarbons between 4 degrees $\mathrm{C}$ and 31 degrees C, Environ. Toxicol., 18, 1905-1912, 1999.

Bourtsoukidis, E., Bonn, B., Dittmann, A., Hakola, H., Hellén, H., and Jacobi, S.: Ozone stress as a driving force of sesquiterpene emissions: a suggested parameterisation, Biogeosciences, 9, 4337-4352, doi:10.5194/bg-9-4337-2012, 2012.

Bouvier-Brown, N. C., Goldstein, A. H., Gilman, J. B., Kuster, W. C., and de Gouw, J. A.: In-situ ambient quantification of monoterpenes, sesquiterpenes, and related oxygenated compounds during BEARPEX 2007: implications for gas- and particle-phase chemistry, Atmos. Chem. Phys., 9, 5505-5518, doi:10.5194/acp-9-5505-2009, 2009a.

Bouvier-Brown, N. C., Holzinger, R., Palitzsch, K., and Goldstein, A. H.: Large emissions of sesquiterpenes and methyl chavicol 
quantified from branch enclosure measurements, Atmos. Environ., 43, 389-401, doi:10.1016/j.atmosenv.2008.08.039, 2009b.

Carlton, A. G., Pinder, R. W., Bhave, P. V., Pouliot, G. A., Alexander, T. W., Park, T., and Carolina, N.: To What Extent Can Biogenic SOA be Controlled?, Environ. Sci. Technol., 44, 33763380, 2010.

Chameides, W. L., Lindsay, R. W., Richardson, J., and Kiang, C. S.: The role of biogenic hydrocarbons in urban photochemical smog: Atlanta as a case study, Science, 241, 1473-1475, 1988.

Chan, A. W. H., Isaacman, G., Wilson, K. R., Worton, D. R., Ruehl, C. R., Nah, T., Gentner, D. R., Dallmann, T. R., Kirchstetter, T. W., Harley, R. A., Gilman, J. B., Kuster, W. C., de Gouw, J. A., Offenberg, J. H., Kleindienst, T. E., Lin, Y. H., Rubitschun, C. L., Surratt, J. D., Hayes, P. L., Jimenez, J. L., and Goldstein, A. H.: Detailed chemical characterization of unresolved complex mixtures in atmospheric organics: Insights into emission sources, atmospheric processing, and secondary organic aerosol formation, J. Geophys. Res.-Atmos., 118, 6783-6796, doi:10.1002/jgrd.50533, 2013.

Chen, F., Tholl, D., Auria, J. C. D., Farooq, A., Pichersky, E., and Gershenzon, J.: Biosynthesis and Emission of Terpenoid Volatiles from Arabidopsis Flowers, Plant Cell, 15, 481-494, doi:10.1105/tpc.007989, 2003.

Chen, Q., Li, Y. L., McKinney, K. A., Kuwata, M., and Martin, S. T.: Particle mass yield from $\beta$-caryophyllene ozonolysis, Atmos. Chem. Phys., 12, 3165-3179, doi:10.5194/acp-12-31652012, 2012.

Chickos, J. S. and Hanshaw, W.: Vapor Pressures and Vaporization Enthalpies of the $\mathrm{n}$-Alkanes from C 21 to C 30 at T $=298.15 \mathrm{~K}$ by Correlation Gas Chromatography, J. Chem. Eng. Data, 49, 77-85, doi:10.1021/je0301747, 2004.

Cubison, M. J., Ortega, A. M., Hayes, P. L., Farmer, D. K., Day, D., Lechner, M. J., Brune, W. H., Apel, E., Diskin, G. S., Fisher, J. A., Fuelberg, H. E., Hecobian, A., Knapp, D. J., Mikoviny, T., Riemer, D., Sachse, G. W., Sessions, W., Weber, R. J., Weinheimer, A. J., Wisthaler, A., and Jimenez, J. L.: Effects of aging on organic aerosol from open biomass burning smoke in aircraft and laboratory studies, Atmos. Chem. Phys., 11, 12049-12064, doi:10.5194/acp-11-12049-2011, 2011.

DeCarlo, P. F., Kimmel, J. R., Trimborn, A., Northway, M. J., Jayne, J. T., Aiken, A. C., Gonin, M., Fuhrer, K., Horvath, T., Docherty, K. S., Worsnop, D. R., and Jimenez, J. L.: Field-Deployable, High-Resolution, Time-of-Flight Aerosol Mass Spectrometer, Anal. Chem., 78, 8281-8289, 2006.

de Gouw, J. and Warneke, C.: Measurements of volatile organic compounds in the earth's atmosphere using proton-transferreaction mass spectrometry, Mass. Spec. Rev., 26, 223-257, 2007

Dewick, P. M.: The biosynthesis of $\mathrm{C}_{5}-\mathrm{C}_{25}$ terpenoid compounds., Nat. Prod. Rep., 14, 111-144, doi:10.1039/np9971400111, 1997.

Di Carlo, P., Brune, W. H., Martinez, M., Harder, H., Lesher, R., Ren, X., Thornberry, T., Carroll, M. A., Young, V., Shepson, P. B., Riemer, D., Apel, E., and Campbell, C.: Missing OH reactivity in a forest: evidence for unknown reactive biogenic VOCs, Science, 304, 722-725, doi:10.1126/science.1094392, 2004

Donahue, N. M., Robinson, A. L., and Pandis, S. N.: Atmospheric organic particulate matter: From smoke to secondary organic aerosol, Atmos. Environ., 43, 94-106, doi:10.1016/j.atmosenv.2008.09.055, 2009.
Draxler, R. and Rolph, G.: HYSPLIT (HYbrid Single-Particle Lagrangian Integrated Trajectory) Model access via NOAA ARL READY Website, available at: http://www.arl.noaa.gov/ HYSPLIT.php (last access: 18 August 2015), 2013.

Duhl, T. R., Helmig, D., and Guenther, A.: Sesquiterpene emissions from vegetation: a review, Biogeosciences, 5, 761-777, doi:10.5194/bg-5-761-2008, 2008.

Eglinton, G., Gonzalez, A. G., Hamilton, R. J., and Raphael, R. A.: Hydrocarbon constituents of the wax coatings of plant leaves: A taxonomic survey, Phytochemistry, 1, 89-102, doi:10.1016/S0031-9422(00)88006-1, 1962.

Ehn, M., Thornton, J. A., Kleist, E., Sipilä, M., Junninen, H., Pullinen, I., Springer, M., Rubach, F., Tillmann, R., Lee, B., LopezHilfiker, F., Andres, S., Acir, I.-H., Rissanen, M., Jokinen, T., Schobesberger, S., Kangasluoma, J., Kontkanen, J., Nieminen, T., Kurtén, T., Nielsen, L. B., Jørgensen, S., Kjaergaard, H. G., Canagaratna, M., Maso, M. D., Berndt, T., Petäjä, T., Wahner, A., Kerminen, V.-M., Kulmala, M., Worsnop, D. R., Wildt, J., and Mentel, T. F.: A large source of low-volatility secondary organic aerosol, Nature, 506, 476-479, doi:10.1038/nature13032, 2014.

Fravel, D. R., Connick, W. J., Grimm, C. C., and Lloyd, S. W.: Volatile compounds emitted by sclerotia of Sclerotinia minor, Sclerotinia sclerotiorum, and Sclerotium rolfsii, J. Agr. Food Chem., 50, 3761-3764, 2002.

Fry, J. L., Draper, D. C., Zarzana, K. J., Campuzano-Jost, P., Day, D. A., Jimenez, J. L., Brown, S. S., Cohen, R. C., Kaser, L., Hansel, A., Cappellin, L., Karl, T., Hodzic Roux, A., Turnipseed, A., Cantrell, C., Lefer, B. L., and Grossberg, N.: Observations of gas- and aerosol-phase organic nitrates at BEACHON-RoMBAS 2011, Atmos. Chem. Phys., 13, 8585-8605, doi:10.5194/acp-138585-2013, 2013.

Gentner, D. R., Isaacman, G., Worton, D. R., Chan, A. W. H., Dallmann, T. R., Davis, L., Liu, S., Day, D. A., Russell, L. M., Wilson, K. R., Weber, R., Guha, A., Harley, R. A., and Goldstein, A. H.: Elucidating secondary organic aerosol from diesel and gasoline vehicles through detailed characterization of organic carbon emissions, P. Natl. Acad. Sci. USA, 109, 18318-18323, doi:10.1073/pnas.1212272109, 2012.

Goldstein, A. H. and Galbally, I. E.: Known and unexplored organic constituents in the earth's atmosphere, Environ. Sci. Technol., 41, 1514-1521, 2007.

Goldstein, A. H., McKay, M., Kurpius, M. R., Schade, G. W., Lee, A., Holzinger, R., and Rasmussen, R. A.: Forest thinning experiment confirms ozone deposition to forest canopy is dominated by reaction with biogenic VOCs, Geophys. Res. Lett., 31, L22106, doi:10.1029/2004GL021259, 2004.

Graus, M., Müller, M., and Hansel, A.: High resolution PTRTOF: Quantification and Formula Confirmation of VOC in Real Time, J. Am. Soc. Mass Spectr., 21, 1037-1044, doi:10.1016/j.jasms.2010.02.006, 2010.

Griffin, R. J., Cocker, D. R., Flagan, R. C., and Seinfeld, J. H.: Organic aerosol formation from the oxidation of biogenic hydrocarbons, J. Geophys. Res., 104, 3555-3567, 1999a.

Griffin, R. J., Cocker, D. R., and Seinfeld, J. H.: Estimate of global atmospheric organic aerosol form oxidation of biogenic hydrocarbons, Geophys. Res. Lett., 26, 2721-2724, 1999 b.

Hallquist, M., Wenger, J. C., Baltensperger, U., Rudich, Y., Simpson, D., Claeys, M., Dommen, J., Donahue, N. M., George, 
C., Goldstein, A. H., Hamilton, J. F., Herrmann, H., Hoffmann, T., Iinuma, Y., Jang, M., Jenkin, M. E., Jimenez, J. L., Kiendler-Scharr, A., Maenhaut, W., McFiggans, G., Mentel, Th. F., Monod, A., Prévôt, A. S. H., Seinfeld, J. H., Surratt, J. D., Szmigielski, R., and Wildt, J.: The formation, properties and impact of secondary organic aerosol: current and emerging issues, Atmos. Chem. Phys., 9, 5155-5236, doi:10.5194/acp-9-51552009, 2009.

Heald, C. L., Ridley, D. A., Kreidenweis, S. M., and Drury, E. E.: Satellite observations cap the atmospheric organic aerosol budget, Geophys. Res. Lett., 37, 6-10, doi:10.1029/2010GL045095, 2010.

Heald, C. L., Coe, H., Jimenez, J. L., Weber, R. J., Bahreini, R., Middlebrook, A. M., Russell, L. M., Jolleys, M., Fu, T.-M., Allan, J. D., Bower, K. N., Capes, G., Crosier, J., Morgan, W. T., Robinson, N. H., Williams, P. I., Cubison, M. J., DeCarlo, P. F., and Dunlea, E. J.: Exploring the vertical profile of atmospheric organic aerosol: comparing 17 aircraft field campaigns with a global model, Atmos. Chem. Phys., 11, 12673-12696, doi:10.5194/acp-11-12673-2011, 2011.

Helmig, D., Klinger, L., Guenther, A., Vierling, L., Geron, C., and Zimmerman, P.: Biogenic volatile organic compound emissions (BVOCs). I. Identifications from three continental sites in the US, Chemosphere, 38, 2163-2187, 1999.

Helmig, D., Ortega, J., Guenther, A., Herrick, J. D., and Geron, C.: Sesquiterpene emissions from loblolly pine and their potential contribution to biogenic aerosol formation in the Southeastern US, Atmos. Environ., 40, 4150-4157, doi:10.1016/j.atmosenv.2006.02.035, 2006.

Henze, D. K. and Seinfeld, J. H.: Global secondary organic aerosol from isoprene oxidation, Geophys. Res. Lett., 33, L09812, doi:10.1029/2006GL025976, 2006.

Holzinger, R., Warneke, C., Hansel, A., Jordan, A., Lindinger, W., Scharffe, D. H., Schade, G., and Crutzen, P. J.: Biomass burning as a source of formaldehyde, acetaldehyde, methanol, acetone, acetonitrile, and hydrogen cyanide, Geophys. Res. Lett., 26, 1161, doi:10.1029/1999GL900156, 1999.

Hoyle, C. R., Boy, M., Donahue, N. M., Fry, J. L., Glasius, M., Guenther, A., Hallar, A. G., Huff Hartz, K., Petters, M. D., Petäjä, T., Rosenoern, T., and Sullivan, A. P.: A review of the anthropogenic influence on biogenic secondary organic aerosol, Atmos. Chem. Phys., 11, 321-343, doi:10.5194/acp-11-321-2011, 2011.

Hsu, Y.-M., Harner, T., Li, H., and Fellin, P.: PAH Measurements in Air in the Athabasca Oil Sands Region, Environ. Sci. Technol., 14, 5584-5592, doi:10.1021/acs.est.5b00178, 2015.

Isaacman, G., Kreisberg, N. M., Worton, D. R., Hering, S. V., and Goldstein, A. H.: A versatile and reproducible automatic injection system for liquid standard introduction: application to in-situ calibration, Atmos. Meas. Tech., 4, 1937-1942, doi:10.5194/amt-4-1937-2011, 2011a.

Isaacman, G., Worton, D. R., Kreisberg, N. M., Hennigan, C. J., Teng, A. P., Hering, S. V., Robinson, A. L., Donahue, N. M., and Goldstein, A. H.: Understanding evolution of product composition and volatility distribution through in-situ $\mathrm{GC} \times \mathrm{GC}$ analysis: a case study of longifolene ozonolysis, Atmos. Chem. Phys., 11, 5335-5346, doi:10.5194/acp-11-5335-2011, 2011 b.

Isaacman, G., Wilson, K. R., Chan, A. W. H., Worton, D. R., Kimmel, J. R., Nah, T., Hohaus, T., Gonin, M., Kroll, J. H., Worsnop, D. R., and Goldstein, A. H.: Improved resolution of hydrocar- bon structures and constitutional isomers in complex mixtures using gas chromatography-vacuum ultraviolet-mass spectrometry., Anal. Chem., 84, 2335-2342, doi:10.1021/ac2030464, 2012.

Isaacman, G., Kreisberg, N. M., Yee, L. D., Worton, D. R., Chan, A. W. H., Moss, J. A., Hering, S. V., and Goldstein, A. H.: Online derivatization for hourly measurements of gas- and particle-phase semi-volatile oxygenated organic compounds by thermal desorption aerosol gas chromatography (SV-TAG), Atmos. Meas. Tech., 7, 4417-4429, doi:10.5194/amt-7-4417-2014, 2014.

Jardine, K., Yañez Serrano, A., Arneth, A., Abrell, L., Jardine, A., van Haren, J., Artaxo, P., Rizzo, L. V., Ishida, F. Y., Karl, T., Kesselmeier, J., Saleska, S., and Huxman T.: Within-canopy sesquiterpene ozonolysis in Amazonia, J. Geophys. Res.-Atmos., 116, D19301, doi:10.1029/2011JD016243, 2011.

Jokinen, T., Berndt, T., Makkonen, R., Kerminen, V.-M., Junninen, H., Paasonen, P., Stratmann, F., Herrmann, H., Guenther, A. B., Worsnop, D. R., Kulmala, M., Ehn, M., and Sipilä, M.: Production of extremely low volatile organic compounds from biogenic emissions: Measured yields and atmospheric implications, P. Natl. Acad. Sci. USA, 112, 7123-7128, doi:10.1073/pnas.1423977112, 2015.

Kallio, M., Jussila, M., Rissanen, T., Anttila, P., Hartonen, K., Reissell, A., Vreuls, R., Adahchour, M., and Hyötyläinen, T.: Comprehensive two-dimensional gas chromatography coupled to time-of-flight mass spectrometry in the identification of organic compounds in atmospheric aerosols from coniferous forest, J. Chrom. A, 1125, 234-243, doi:10.1016/j.chroma.2006.05.050, 2006.

Kaser, L., Karl, T., Schnitzhofer, R., Graus, M., Herdlinger-Blatt, I. S., DiGangi, J. P., Sive, B., Turnipseed, A., Hornbrook, R. S., Zheng, W., Flocke, F. M., Guenther, A., Keutsch, F. N., Apel, E., and Hansel, A.: Comparison of different real time VOC measurement techniques in a ponderosa pine forest, Atmos. Chem. Phys., 13, 2893-2906, doi:10.5194/acp-13-2893-2013, 2013.

Kim, S., Guenther, A., Karl, T., and Greenberg, J.: Contributions of primary and secondary biogenic VOC tototal $\mathrm{OH}$ reactivity during the CABINEX (Community Atmosphere-Biosphere INteractions Experiments)-09 field campaign, Atmos. Chem. Phys., 11, 8613-8623, doi:10.5194/acp-11-8613-2011, 2011.

Kurpius, M. R. and Goldstein, A. H.: Gas-phase chemistry dominates $\mathrm{O} 3$ loss to a forest, implying a source of aerosols and hydroxyl radicals to the atmosphere, Geophys. Res. Lett., 30, 1371, doi:10.1029/2002GL016785, 2003.

Lee, A., Goldstein, A., Keywood, M., Gao, S., Varutbangkul, V., Bahreini, R., Ng, N. L., Flagan, R. C., and Seinfeld, J. H.: Gasphase products and secondary aerosol yields from the ozonolysis of ten different terpenes, J. Geophys. Res.-Atmos., 111, D07302, doi:10.1029/2005JD006437, 2006a.

Lee, A., Goldstein, A. H., Kroll, J. H., Ng, N. L., Varutbangkul, V., Flagan, R. C., and Seinfeld, J. H.: Gas-phase products and secondary aerosol yields from the photooxidation of 16 different terpenes, J. Geophys. Res.-Atmos., 111, D17305, doi:10.1029/2006JD007050, 2006b.

Ng, N. L., Chhabra, P. S., Chan, A. W. H., Surratt, J. D., Kroll, J. H., Kwan, A. J., McCabe, D. C., Wennberg, P. O., Sorooshian, A., Murphy, S. M., Dalleska, N. F., Flagan, R. C., and Seinfeld, J. H.: Effect of $\mathrm{NO}_{x}$ level on secondary organic aerosol (SOA) 
formation from the photooxidation of terpenes, Atmos. Chem. Phys., 7, 5159-5174, doi:10.5194/acp-7-5159-2007, 2007.

Nölscher, A. C., Williams, J., Sinha, V., Custer, T., Song, W., Johnson, A. M., Axinte, R., Bozem, H., Fischer, H., Pouvesle, N., Phillips, G., Crowley, J. N., Rantala, P., Rinne, J., Kulmala, M., Gonzales, D., Valverde-Canossa, J., Vogel, A., Hoffmann, T., Ouwersloot, H. G., Vilà-Guerau de Arellano, J., and Lelieveld, J.: Summertime total $\mathrm{OH}$ reactivity measurements from boreal forest during HUMPPA-COPEC 2010, Atmos. Chem. Phys., 12, 8257-8270, doi:10.5194/acp-12-8257-2012, 2012.

Ormeño, E., Gentner, D. R., Fares, S., Karlik, J., Park, J. H., and Goldstein, A. H.: Sesquiterpenoid emissions from agricultural crops: correlations to monoterpenoid emissions and leaf terpene content, Environ. Sci. Technol., 44, 3758-3764, doi:10.1021/es903674m, 2010.

Ortega, J., Turnipseed, A., Guenther, A. B., Karl, T. G., Day, D. A., Gochis, D., Huffman, J. A., Prenni, A. J., Levin, E. J. T., Kreidenweis, S. M., DeMott, P. J., Tobo, Y., Patton, E. G., Hodzic, A., Cui, Y. Y., Harley, P. C., Hornbrook, R. S., Apel, E. C., Monson, R. K., Eller, A. S. D., Greenberg, J. P., Barth, M. C., CampuzanoJost, P., Palm, B. B., Jimenez, J. L., Aiken, A. C., Dubey, M. K., Geron, C., Offenberg, J., Ryan, M. G., Fornwalt, P. J., Pryor, S. C., Keutsch, F. N., DiGangi, J. P., Chan, A. W. H., Goldstein, A. H., Wolfe, G. M., Kim, S., Kaser, L., Schnitzhofer, R., Hansel, A., Cantrell, C. A., Mauldin, R. L., and Smith, J. N.: Overview of the Manitou Experimental Forest Observatory: site description and selected science results from 2008 to 2013, Atmos. Chem. Phys., 14, 6345-6367, doi:10.5194/acp-14-6345-2014, 2014.

Paatero, P.: User's guide for positive matrix factorization programs PMF2.EXE and PMF3.EXE, Tech. rep., University of Helsinki, Finland, 2007.

Paatero, P. and Tapper, U.: Positive matrix factorization: A nonnegative factor model with optimal utilization of error estimates of data values, Environmetrics, 5, 111-126, 1994.

Pankow, J. F.: An absorption model of gas/particle partitioning of organic compounds in the atmosphere, Atmos. Environ., 28, 185-188, doi:10.1016/1352-2310(94)90093-0, 1994.

Pankow, J. F. and Asher, W. E.: SIMPOL.1: a simple group contribution method for predicting vapor pressures and enthalpies of vaporization of multifunctional organic compounds, Atmos. Chem. Phys., 8, 2773-2796, doi:10.5194/acp-8-27732008, 2008.

Pankow, J. F., Luo, W., Melnychenko, A. N., Barsanti, K. C., Isabelle, L. M., Chen, C., Guenther, A. B., and Rosenstiel, T. N.: Volatilizable Biogenic Organic Compounds (VBOCs) with two dimensional Gas Chromatography-Time of Flight Mass Spectrometry (GC $\times$ GC-TOFMS): sampling methods, VBOC complexity, and chromatographic retention data, Atmos. Meas. Tech., 5, 345-361, doi:10.5194/amt-5-345-2012, 2012.

Park, J.-H., Fares, S., Weber, R., and Goldstein, A. H.: Biogenic volatile organic compound emissions during BEARPEX 2009 measured by eddy covariance and flux-gradient similarity methods, Atmos. Chem. Phys., 14, 231-244, doi:10.5194/acp-14-2312014, 2014.

Pollmann, J., Ortega, J., and Helmig, D.: Analysis of atmospheric sesquiterpenes: sampling losses and mitigation of ozone interferences, Environ. Sci. Technol., 39, 9620-9629, 2005.

Rissanen, T., Hyötyläinen, T., Kallio, M., Kronholm, J., Kulmala, M., and Riekkola, M.-L.: Characterization of organic compounds in aerosol particles from a coniferous forest by GC-MS, Chemosphere, 64, 1185-1195, doi:10.1016/j.chemosphere.2005.11.079, 2006.

Rogge, W. F., Mazurek, M. A., Hildemann, L. M., Cass, G. R., and Simoneit, B. R. T.: Quantification of urban organic aerosols at a molecular level: identification, abundance and seasonal variation, Atmos. Environ., 27A, 1309-1330, doi:10.1016/09601686(93)90257-Y, 1993.

Roux, M. V., Temprado, M., Chickos, J. S., and Nagano, Y.: Critically evaluated thermochemical properties of polycyclic aromatic hydrocarbons, J. Phys. Chem. Ref. Data, 37, 1855-1996, doi:10.1063/1.2955570, 2008.

Schneider, J., Weimer, S., Drewnick, F., Borrmann, S., Helas, G., Gwaze, P., Schmid, O., Andreae, M., and Kirchner, U.: Mass spectrometric analysis and aerodynamic properties of various types of combustion-related aerosol particles, Int. J. Mass Spectrom., 258, 37-49, doi:10.1016/j.ijms.2006.07.008, 2006.

Simoneit, B. R. T.: Biomass burning - a review of organic tracers for smoke from incomplete combustion, Appl. Geochem., 17, 129162, 2002.

Sinha, V., Williams, J., Lelieveld, J., Ruuskanen, T. M., Kajos, M. K., Patokoski, J., Hellen, H., Hakola, H., Mogensen, D., Boy, M., Rinne, J., and Kulmala, M.: OH reactivity measurements within a boreal forest: Evidence for unknown reactive emissions, Environ. Sci. Technol., 44, 6614-6620, doi:10.1021/es101780b, 2010.

Spracklen, D. V., Jimenez, J. L., Carslaw, K. S., Worsnop, D. R., Evans, M. J., Mann, G. W., Zhang, Q., Canagaratna, M. R., Allan, J., Coe, H., McFiggans, G., Rap, A., and Forster, P.: Aerosol mass spectrometer constraint on the global secondary organic aerosol budget, Atmos. Chem. Phys., 11, 12109-12136, doi:10.5194/acp-11-12109-2011, 2011.

Stein, S. E.: Estimating probabilities of correct identification from results of mass spectral library searches, J. Am. Soc. Mass Spectr., 5, 316-323, doi:10.1016/1044-0305(94)85022-4, 1994.

Ulbrich, I. M., Canagaratna, M. R., Zhang, Q., Worsnop, D. R., and Jimenez, J. L.: Interpretation of organic components from Positive Matrix Factorization of aerosol mass spectrometric data, Atmos. Chem. Phys., 9, 2891-2918, doi:10.5194/acp-9-2891-2009, 2009.

Wania, F., Haugen, J. E., Lei, Y. D., and Mackay, D.: Temperature dependence of atmospheric concentrations of semivolatile organic compounds, Environ. Sci. Technol., 32, 1013-1021, doi:10.1021/es970856c, 1998.

Williams, J.: Organic Trace Gases in the Atmosphere: An Overview, Environ. Chem., 1, 125-136, 2004.

Williams, B. J., Goldstein, A. H., Kreisberg, N. M., Hering, S. V., Worsnop, D. R., Ulbrich, I. M., Docherty, K. S., and Jimenez, J. L.: Major components of atmospheric organic aerosol in southern California as determined by hourly measurements of source marker compounds, Atmos. Chem. Phys., 10, 11577-11603, doi:10.5194/acp-10-11577-2010, 2010.

Williams, B. J., Jayne, J. T., Lambe, A. T., Hohaus, T., Kimmel, J. R., Sueper, D., Brooks, W., Williams, L. R., Trimborn, A. M., Martinez, R. E., Hayes, P. L., Jimenez, J. L., Kreisberg, N. M., Hering, S. V., Worton, D. R., Goldstein, A. H., and Worsnop, D. R.: The First Combined Thermal Desorption Aerosol Gas Chromatograph-Aerosol Mass 
Spectrometer (TAG-AMS), Aerosol Sci. Tech., 48, 358-370, doi:10.1080/02786826.2013.875114, 2014.

Worton, D. R., Goldstein, A. H., Farmer, D. K., Docherty, K. S., Jimenez, J. L., Gilman, J. B., Kuster, W. C., de Gouw, J., Williams, B. J., Kreisberg, N. M., Hering, S. V., Bench, G., McKay, M., Kristensen, K., Glasius, M., Surratt, J. D., and Seinfeld, J. H.: Origins and composition of fine atmospheric carbonaceous aerosol in the Sierra Nevada Mountains, California, Atmos. Chem. Phys., 11, 10219-10241, doi:10.5194/acp-1110219-2011, 2011

Zhang, H., Worton, D. R., Lewandowski, M., Ortega, J., Rubitschun, C. L., Park, J.-H., Kristensen, K., Campuzano-Jost, P., Day, D. A., Jimenez, J. L., Jaoui, M., Offenberg, J. H., Kleindienst, T. E., Gilman, J., Kuster, W. C., de Gouw, J., Park, C., Schade, G. W., Frossard, A. A., Russell, L., Kaser, L., Jud, W., Hansel, A., Cappellin, L., Karl, T., Glasius, M., Guenther, A., Goldstein, A. H., Seinfeld, J. H., Gold, A., Kamens, R. M., and Surratt, J. D.: Organosulfates as tracers for secondary organic aerosol (SOA) formation from 2-methyl-3-buten-2-ol (MBO) in the atmosphere., Environ. Sci. Technol., 46, 94379446, doi:10.1021/es301648z, 2012.
Zhao, Y., Kreisberg, N. M., Worton, D. R., Isaacman, G., Gentner, D. R., Chan, A. W. H., Weber, R. J., Liu, S., Day, D. A., Russell, L. M., Hering, S. V., and Goldstein, A. H.: Sources of organic aerosol investigated using organic compounds as tracers measured during CalNex in Bakersfield, J. Geophys. Res.-Atmos., 118, 11388-11398, doi:10.1002/jgrd.50825, $2013 \mathrm{a}$.

Zhao, Y., Kreisberg, N. M., Worton, D. R., Teng, A. P., Hering, S. V., and Goldstein, A. H.: Development of an In Situ Thermal Desorption Gas Chromatography Instrument for Quantifying Atmospheric Semi-Volatile Organic Compounds, Aerosol Sci. Tech., 47, 258-266, doi:10.1080/02786826.2012.747673, 2013b. 